\author{
SANDIA REPORT \\ SAND2009-6545 \\ Unlimited Release \\ Printed October 2009
}

\title{
Nambe Pueblo Water Budget and Forecasting Model
}

\author{
J. R. Brainard
}

Prepared by

Sandia National Laboratories

Albuquerque, New Mexico 87185 and Livermore, California 94550

Sandia is a multiprogram laboratory operated by Sandia

Corporation, a Lockheed Martin Company, for the United States

Department of Energy under Contract DE-AC04-94AL85000.

Approved for public release; further dissemination unlimited.

\section{A. Sandia National Laboratories}

Issued by Sandia National Laboratories, operated for the United States Department of Energy by Sandia Corporation.

NOTICE: This report was prepared as an account of work sponsored by an agency of the United States Government. Neither the United States Government, nor any agency thereof, nor any of their employees, nor any of their contractors, subcontractors, or their employees, make any warranty, express or implied, or assume any legal liability or responsibility for the 
accuracy, completeness, or usefulness of any information, apparatus, product, or process disclosed, or represent that its use would not infringe privately owned rights. Reference herein to any specific commercial product, process, or service by trade name, trademark, manufacturer, or otherwise, does not necessarily constitute or imply its endorsement, recommendation, or favoring by the United States Government, any agency thereof, or any of their contractors or subcontractors. The views and opinions expressed herein do not necessarily state or reflect those of the United States Government, any agency thereof, or any of their contractors.

Printed in the United States of America. This report has been reproduced directly from the best available copy.

Available to DOE and DOE contractors from

U.S. Department of Energy

Office of Scientific and Technical Information

P.O. Box 62

Oak Ridge, TN 37831

Telephone: (865)576-8401

Facsimile: (865)576-5728

E-Mail: $\quad$ reports@adonis.osti.gov

Online ordering: http://www.doc.gov/bridge

Available to the public from

U.S. Department of Commerce

National Technical Information Service

5285 Port Royal Rd.

Springfield, VA 22161

Telephone: (800)553-6847

Facsimile: (703)605-6900

E-Mail: $\quad$ orders@ntis.fedworld.gov

Online ordering: http://www.ntis.gov/ordering.htm

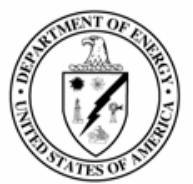


SAND2009-6545

Unlimited Release

Printed October 2009

\title{
Nambe Pueblo Water Budget and Forecasting Model
}

\author{
J. R Brainard \\ National Security Applications Department 6731 \\ Nuclear Energy and Global Security \\ Sandia National Laboratories \\ P.O. Box 5800 \\ Albuquerque, New Mexico 87185-1324
}

\begin{abstract}
This report documents The Nambe Pueblo Water Budget and Water Forecasting model. The model has been constructed using Powersim Studio (PS), a software package designed to investigate complex systems where flows and accumulations are central to the system. Here PS has been used as a platform for modeling various aspects of Nambe Pueblo's current and future water use.

The model contains three major components, the Water Forecast Component, Irrigation Scheduling Component, and the Reservoir Model Component. In each of the components, the user can change variables to investigate the impacts of water management scenarios on future water use. The Water Forecast Component includes forecasting for industrial, commercial, and livestock use. Domestic demand is also forecasted based on user specified current population, population growth rates, and per capita water consumption.

Irrigation efficiencies are quantified in the Irrigated Agriculture component using critical information concerning diversion rates, acreages, ditch dimensions and seepage rates. Results from this section are used in the Water Demand Forecast, Irrigation Scheduling, and the Reservoir Model components.

The Reservoir Component contains two sections, 1) Storage and Inflow Accumulations by Categories and 2) Release, Diversion and Shortages. Results from both sections are derived from the calibrated Nambe Reservoir model where historic, pre-dam or above dam USGS stream flow data is fed into the model and releases are calculated.
\end{abstract}




\section{Acknowledgments}

Construction of the Nambe Pueblo water budget model would not have been possible with out the persistent support and input from Governor Ernst Mirabal and Herbert Yeats. Mr. Mirabal and Mr. Yeats expressed genuine interest in the progress of the development of the model throughout the project and consistently provided invaluable information on the workings of Nambe Pueblo's irrigation system. I would also like to thank the late Benjamin Yeats, someone who I hardly new, someone I was hoping to get to know, someone who impressed me as having the great spirit of life within him, thank you Ben for the kind support and enthusiasm you showed for Nambe Pueblo Water Budget and Forecasting model. 
This page intentionally left blank. 


\section{Contents}

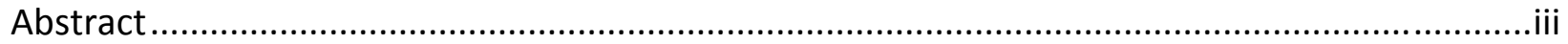

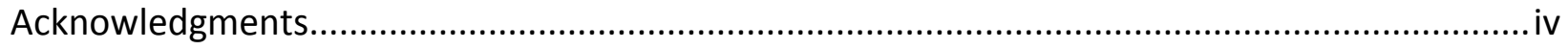

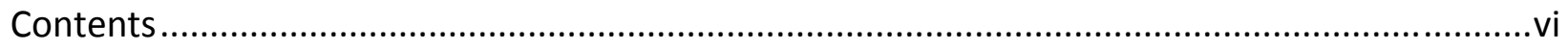

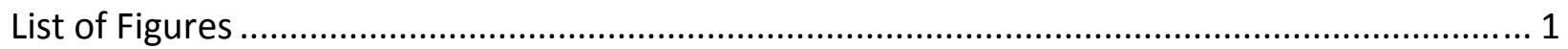

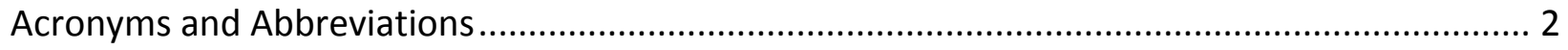

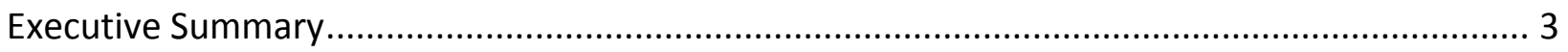

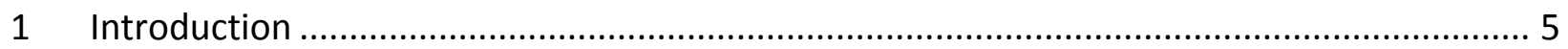

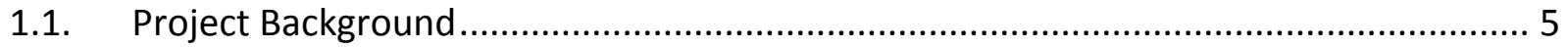

1.2. Nambe Pueblo Lands and Water Use ................................................................ 5

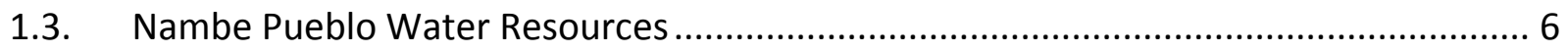

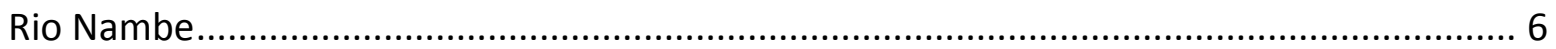

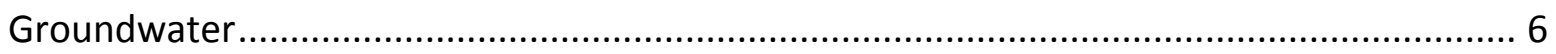

1.4. Nambe Pueblo Water Use Overview ............................................................... 6

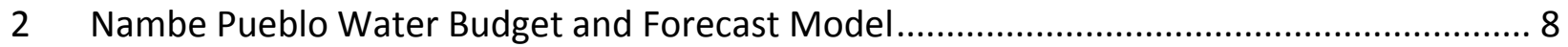

2.1. Model Introduction ............................................................................................. 8

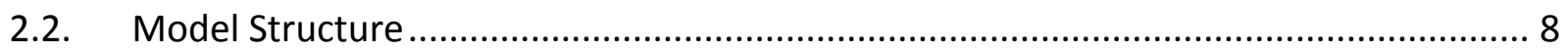

3 Water Demand Forecast Component ........................................................................ 10

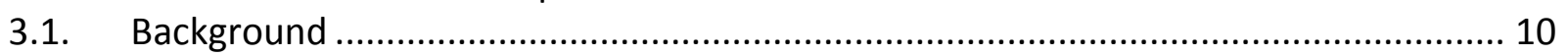

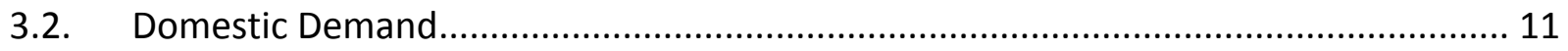

3.3. Industrial, Commercial, and Livestock Demand .................................................... 12

$4 \quad$ Irrigated Agriculture Component............................................................................ 15

4.1. Irrigated Agricultural System Description....................................................... 15

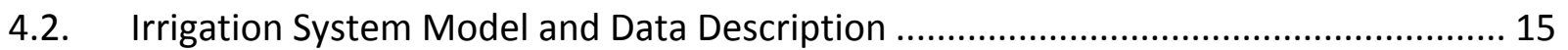

4.3. Irrigated Agriculture User Interface Description .............................................. 18

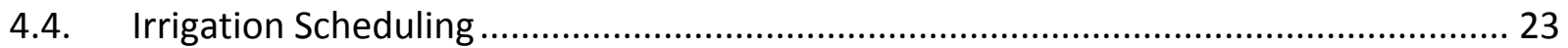

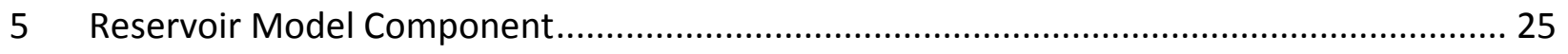

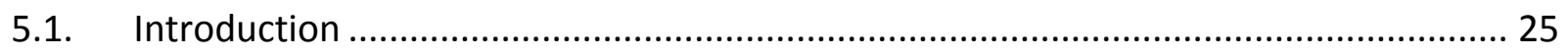

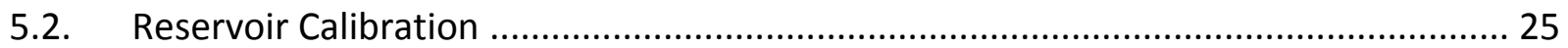

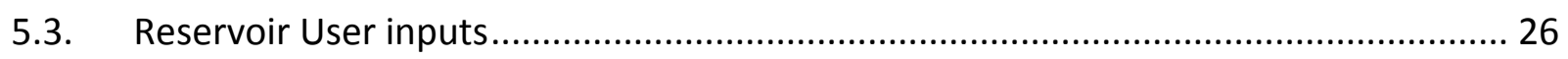

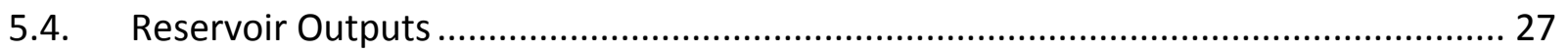

Nambe Pueblo Storage Estimates and Inflow Accumulation ........................................ 27

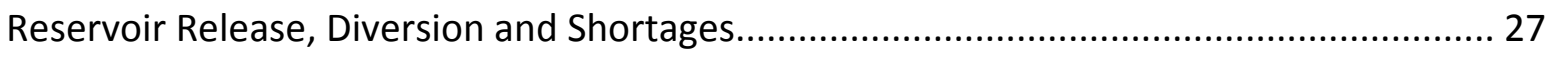

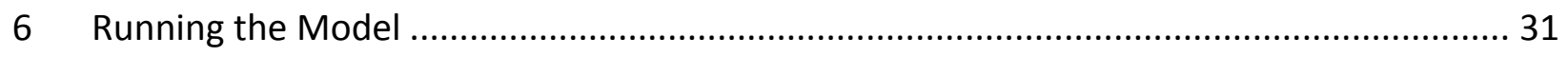

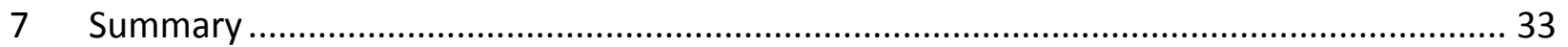

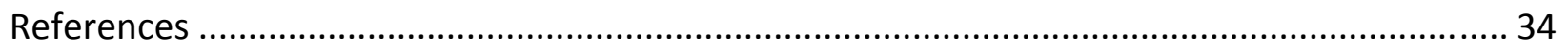

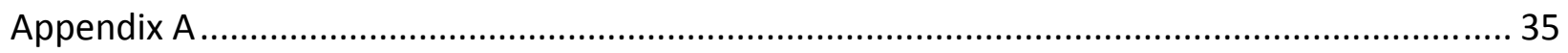

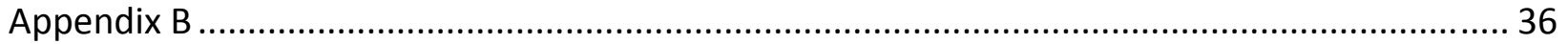




\section{List of Figures}

Figure 1-1: Screen shot of the Table of Contents page ........................................................... 7

Figure 2-1: Screen shot of the Model Structure page. ........................................................ 9

Figure 3-1: Screen shot of the Water Demand Forecast Page. .................................................. 10

Figure 3-2: Screen shot of the Domestic Water Demand User Interface.................................. 11

Figure 3-3: Screen shot of the Industrial Demand user interface. ......................................... 12

Figure 3-4: Screen shot of the Commercial Demand user interface......................................... 13

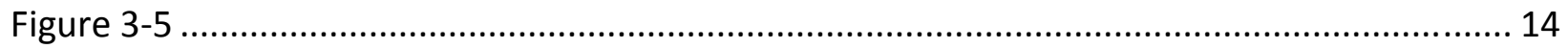

Figure 4-1: Areal photograph (USGS Digital Orthophoto Quadrangle based map) showing the Rio Nambe, the Highline and Consolidated irrigation ditches, and irrigated farms within the Nambe

Pueblo lands............................................................................................................. 16

Figure 4-2: Schematic of the Nambe Pueblo Irrigation system ................................................ 17

Figure 4-4: Screen shot of the Irrigated Agriculture Demand Table of Contents Page............... 22

Figure 4-5: Screen shot of the first page of the Irrigated Agriculture component interface showing the user input slider in the upper half of the screen and the interface outputs in the

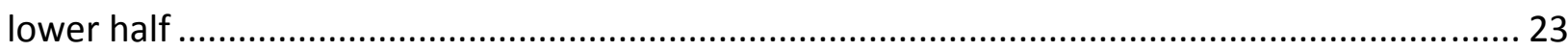

Figure 4-3: Screen shot of the Irrigation Scheduling output page. .......................................... 24

Figure 5-1: Screen shot of the Storage and Inflow Accumulations by Categories page ............. 28

Figure 5-2: Screen shot of the Release, Diversion, and Shortages page .................................. 29

Figure 5-3: Screen shot of the Cumulative Water Year Flow and Stream Flow plots. ................ 31 


\section{Acronyms and Abbreviations}

af: acre-feet

cfs: cubic feet per second

CIR: Consumptive Irrigation Requirement

ET: evapotranspiration

Ft: foot or feet

gpd: gallons per day

NMSBA: New Mexico Small Business Assistance Program

OSE: Office of the State Engineer

PS: Powersim Studio ${ }^{\circledR}$

PVID: Pojoaque Valley Irrigation District

SJP: San Juan Project

SNL: Sandia National Laboratories

USACE: U.S. Army Corps of Engineers

USBR: United States Bureau of Reclamation

USDA: United States Department of Agriculture

USFS: United States Forest Service

USGS: Unite States Geological Survey

Yr: year 


\section{Executive Summary}

This report documents The Nambe Pueblo Water Budget and Water Forecasting Model. The model has been constructed using Powersim Studio ${ }^{\circledR}$ (PS), a software package designed to investigate complex systems where flows and accumulations are central to the system. Here PS has been used to model the Nambe Pueblo current and future water use.

The model contains three major components, the Water Forecast Component, Irrigation Scheduling Component, and the Reservoir Model Component. The user can change variables to investigate the impacts of water management scenarios on future water use. The Water Forecast Component includes forecasting for industrial, commercial, and livestock use based on user inputs that specify start dates, initial water consumption, growth rate and maximum water consumption. In the case of livestock, maximum heard size is used instead of maximum consumption. Domestic demand is also forecasted based on user specified current population, population growth rates, and per capita water consumption.

The Irrigated Agriculture section is a significant part of the model. Results from this section are used in the Water Demand Forecast, Irrigation Scheduling, and the Reservoir Model

components. In the agriculture section, the user has numerous options for investigating irrigation efficiencies through changes in diversion rates and improvements in irrigation ditch infrastructure. The Water Demand Forecast Component adds the diversion demand calculated in the Irrigated Agriculture Section to that of the other water use categories.

The Irrigation Scheduling Section contains comparisons between three irrigation schedules, a top down schedule where irrigation commences at the first field at the top of the system and continues in sequence to the last field, a bottom up schedule where the opposite occurs, and a random schedule.

The Reservoir Component contains two sections, both of which use input from thirty three years of United States Geological Survey (USGS) gauging station data. The Storage and Inflow Accumulations by Categories section calculates Nambe Pueblo storage in the Nambe Reservoir as a function of time using a calibrated reservoir model where upstream of the reservoir and pre dam USGS stream flow data are fed into the reservoir model and the out flow is simulated. This section also tracks the accumulation of several categories of stream flow of interest to Nambe Pueblo over time.

The Release, Diversion, and Shortages section of the Reservoir Component also uses the calibrated reservoir. This component is used to explore the impact that shortages and abundant water have on the duration of irrigation events and tracks the number of days that user set irrigation diversion rates are not met. Both of these results are dependent on user selected values in the Irrigated Agriculture Section which provides the ability to evaluate the impacts of irrigation efficiency on Nambe Pueblo reservoir storage and irrigation shortages. To use the model, the user changes the value of variables through slider bars, adjustable graphs, and tables. In the Domestic Demand and Irrigated Agriculture Demand components, the model calculates some out-put instantaneously as the input values are changed. In contrast, water use forecasting and reservoir related calculations require the model to be "ran". This means that the model does a new calculation on each time step starting with a "start time", and continues to run until the "stop time". As a result of this process, calculated results 
for each time step are displayed on time series plots. The Nambe Pueblo Model is set up to run over two different intervals and two different time steps. The Water Forecast Component runs from $10 / 1 / 2001$ to $12 / 1 / 2061$ with a 7 day time step while the Irrigation Scheduling and Reservoir Components run for three years (the user chooses the years to run the model over) with a 0.5 day time step.

The Nambe Pueblo Water Budget and Forecast Model is a complex compilation of measured data and calculations and, yet the model is accessible to the non-technical user through a user friendly interface. Time and effort on the part of the user are required to gain insight into the implications of the model results, to evaluate the model for inaccuracies, and to identify improvements that may help Nambe Pueblo gain a better understanding of their future water use. The author encourages users to provide feedback so that shortcomings in the model can be assessed and corrected and other changes can be made that improves the utility of the model to Nambe Pueblo. 


\section{Introduction}

\section{Project Background}

This report documents The Nambe Pueblo Water Budget and Water Forecasting Model which was developed specifically to quantify current and future water use on Nambe Pueblo lands. This report serves as 1 ) a reference of data sources 2) documentation of model calculations and 3) a manual that helps to familiarize users with the user interface. Model outcomes are based on user selected inputs related to both water use efficiencies and forecast variables such as future population growth, resident population growth and irrigated acreages. The user can easily change the inputs, run the model and observe the output in a matter of minutes. The funding for this project was provided by the Sandia National Laboratories (SNL) New Mexico Small Business Assistance Program (NMSBA) where businesses can sponsor NMSBA projects to gain technical assistance from Sandia and Los Alamos National Laboratories. The technical assistance must address problems that will be of economic benefit to an individual business or a group of business with a common problem.

This project was supported with several Sole Proprietorship agriculture businesses within the Nambe Pueblo and has a potential to help the irrigation community on the Pueblo to both prioritizing capital improvements and to develop quantitative arguments for making those improvements. These capital improvements in turn would increase irrigation efficiencies and would result in more production per acre from the existing irrigated acreage or result in increased irrigated acreage. Other economic benefits of the model to Nambe Pueblo include the time savings in acquiring the data for, and development of a similar model that could be used for quantifying current and future water use on the Pueblo.

The Nambe Pueblo Water Budget and Water Forecasting Model consists of several sections, each addressing a unique component water use at Nambe Pueblo. The model is built on the Powersim Studio software, a personal computer based software package specifically designed for development of mathematical models that capture complex interdependencies between systems components and allows end users to investigate system behavior through a user friendly interface.

\section{Nambe Pueblo Lands and Water Use}

The Nambe Pueblo lands are located in the western foothills of the Sangre de Cristo Mountains of north central New Mexico in northern Santa Fe County. The eastern boundary of Nambe Pueblo lands abuts the United States Forest Service (USFS) Pecos Wilderness. Most of the 19,000 acre reservation land and the entire developed portion of Nambe Pueblo are within the Rio Nambe drainage basin and concentrated adjacent to the Rio Nambe.

Upstream of the Nambe Pueblo developed lands on the Rio Nambe, and within the Nambe Pueblo lands is the United States Bureau of Reclamation (USBR) San Juan-Project (SJP) Nambe Reservoir. This reservoir provides shared storage for Nambe, San Ildefonso, Pojoaque Pueblos and non-Indian surface water irrigators. All of the irrigation water users along the Rio Nambe 
are members of the Pojoaque Valley Irrigation District (PVID), an intermediary administrative organization that manages transaction between the PVID irrigators and the USBR's SJP. Within the boundaries of Nambe Pueblo are numerous private non-Indian in-holdings, most, if not all of which are located within the irrigated areas adjacent to the Rio Nambe. These private lands include currently irrigated fields and fields that have been converted to residential lots. Irrigation water for the non-Indian fields is provided through irrigation ditches shared with Nambe Pueblo.

Nambe Pueblo obtains all of its non-irrigation water from two wells located within the populated area of the pueblo. Well water is predominantly used for domestic use and, perhaps a small percentage is used for livestock watering.

\section{Nambe Pueblo Water Resources}

\section{Rio Nambe}

The Rio Nambe basin reaches an elevation of 12,600 feet to the east within the Pecos Wilderness of Santa Fe National Forest and drains an area of 35 square miles. Nambe Reservoir, constructed as part of the SJC project with the first year of water impoundment in 1976 , has a dam crest elevation of 6840 feet above mean sea level and is on record with the USBR as having 2023 acre feet (af) of storage with an active storage capacity of 1665 af. However, sediment inflows since dam construction may have decreased the active storage. In particular considerable sediment was deposited in the reservoir following an intense monsoonal rainstorm of August 10, 2003 following the June and July Molina Complex fire in Pecos Wilderness.

Rio Nambe yearly flow statistics from three USGS stream gaging stations as reported in the Jemez Y Sangre Regional Water Plan are as follows: pre-dam cumulative flow for the years of 1932 to 1997 and 1963 to 1978 is 7652 af/yr 7384 af/yr respectively while post dam cumulative flows for the years of 1984 to 1997 is 11655 af/year.

\section{Groundwater}

Ground water provides Nambe Pueblo with domestic water and other water uses. Nambe Pueblo has two domestic wells that feed water to storage tanks and distributes the water to homes through a subsurface network of pipes. Nambe Pueblo does not have a water treatment plant; rather effluent is either routed to septic systems or to two open air sewerage ponds within Nambe Pueblo lands.

\section{Nambe Pueblo Water Use Overview}

Water use in New Mexico is typically divided in to five categories by the New Mexico Office of the State Engineer (OSE):

- Public water supply and self-supplied domestic

- Irrigated agriculture

- Self-supplied livestock

- Industrial

- Self supplied commercial

- Mining 
- Power

- Reservoir Evaporation

Of these categories, Nambe Pueblo water use currently consists of domestic, irrigated agriculture, livestock, and commercial. Nambe Pueblo does not have an industrial use for water. Nambe Pueblo owns and operates the Nambe Falls Travel Center, located south of the town of Pojoaque, N. M. on U.S. 285 several miles to the southwest of Nambe Pueblo. Water for the travel center is Nambe Pueblo's only current commercial water use. The water supply for the travel center is obtained from a well adjacent to the center. Nambe Pueblo's potential commercial water use includes water for a Casino and a Hotel. Potential industrial use includes water for a bottled water plant. Nambe Pueblo has no plans to use water for mines or power generation. Evaporation from Nambe Reservoir is distributed among all PVID users on a monthly basis and proportional to the average monthly reservoir storage of each user. The USBR is charged with tracking reservoir evaporation losses and assigning losses to the water storage uses.

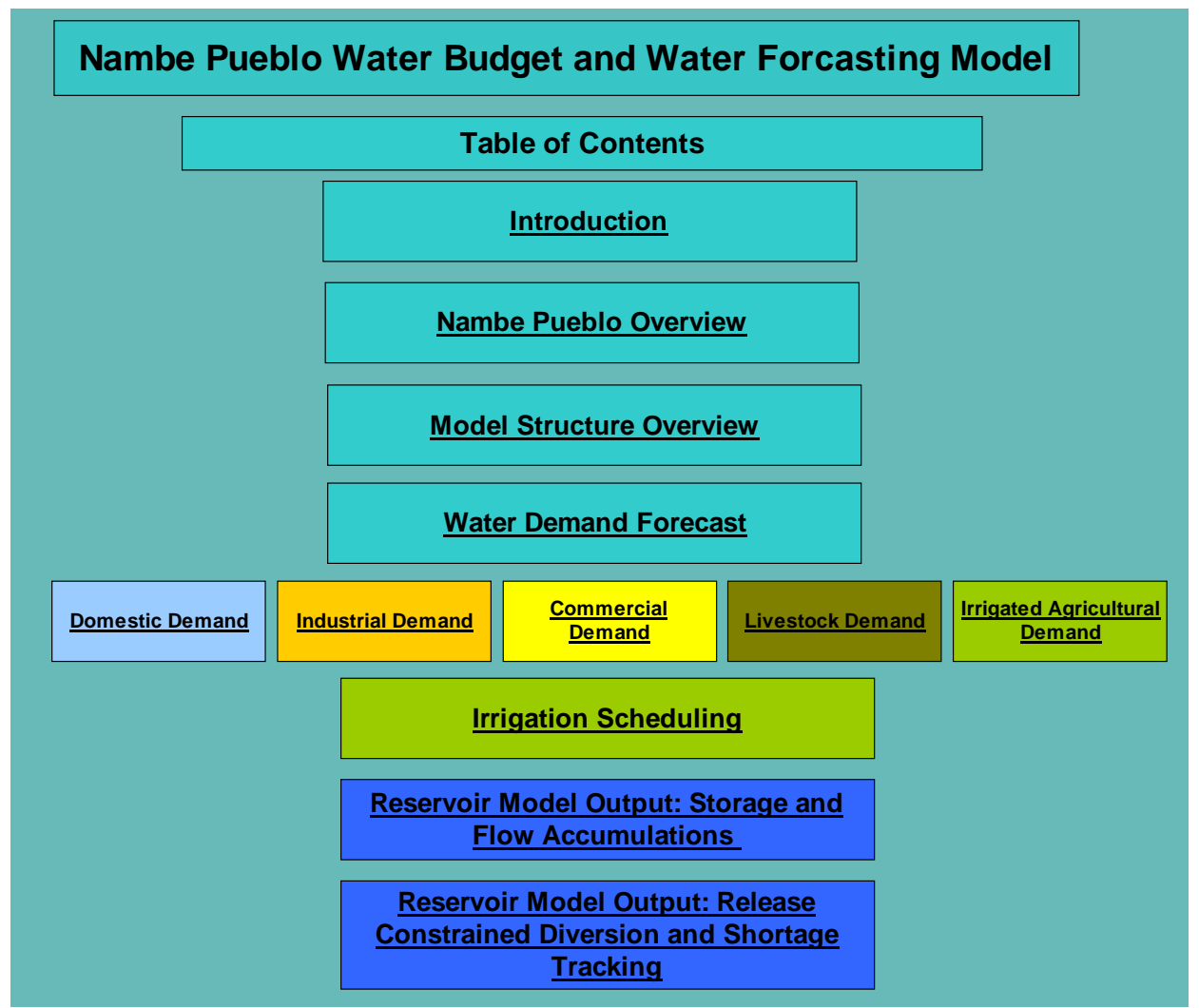

Figure 0-1: Screen shot of the Table of Contents page. This is the page the model opens to upon start-up. From this page the user can move to any one of the sections in the model by double clicking on the text boxes. The components of the model are accessed through this page as well as pages with additional information such as the Introduction, Nambe Pueblo Overview and the Model Structure Overview pages. 


\section{Nambe Pueblo Water Budget and Forecast Model}

\section{Model Introduction}

The Nambe Pueblo Water Budget and Forecast Model addresses current and potential water use within Nambe Pueblo. The model has three major components: 1) a Water Demand Forecast component that accumulates yearly water use/consumption based on user specified inputs related to current and future domestic, industrial, commercial, and agricultural uses, 2) an Irrigated Agricultural component which has an extensive user interface that allows for exploring irrigation efficiencies, and 3) a Reservoir Model component where a calibrated reservoir model calculates Nambe Pueblo storage, flow accumulations for different categories of inflow, irrigation demand deficits, and total days of deficits as a function of varying climate as reflected in historical Rio Nambe pre-dam flow data from the USGS. As part of the Domestic demand component, housing demand is also forecasted.

The model performs two types of calculations, those that are time dependent and those that are time independent. The time dependent calculations require that the model be "ran" in

order to see the results. Time independent calculations occur as the user adjusts variables. The "How to Run the Model" section gives instructions for running the model.

The components of the model are described in individual sections starting with the description of the model's Table of Contents. All the pages in the model contain hyperlinks which appear as text boxes with the underlined text. Starting with the Table of Contents, the user can move to all of the model pages through these hyperlinks. Hyperlinks also take the user back to the Table of Contents page (see Figure 0-1 below) or to the Model Structure page; a page that graphically shows the relation between the various components and pages of the model (See the next section). Other hyperlinks give easy access pages that use user input information from another page for its calculations. The Table of Contents page also has hyperlinks to the Introduction and Nambe Pueblo Overview pages. The introduction presents the same information presented in the introduction of this report while the Nambe Pueblo Overview page contains a photographic collage illustrating Nambe Pueblo's surface water resources and its agricultural use of that water.

\section{Model Structure}

The Model Structure page (Figure 0-1) schematically illustrates the three model components described in Section 2.1 and shows the relationship between the various component pages. The three components are titled 1) Forecast Model, 2) Irrigated Agriculture Model, and 3) Reservoir Model. For the Forecast Model, the box at the top of Figure 0-1, illustrates that the Domestic, Industrial, Commercial, Livestock, and Irrigated Agricultural user inputs are used to calculate the total demand for each category and that these results are used in the output on the Water Demand Forecast page. The box in the lower left hand corner of Figure 0-1 illustrates that the Irrigated Agricultural Demand Inputs are used in the Irrigated Agriculture Model where the impacts of infrastructure improvements and irrigation schedules on efficiencies can be investigated. Irrigated agriculture also plays a role in the Reservoir Model (lower right hand side of the page) where user selected river diversion rates and other parameters associated 
with irrigation efficiencies are used to investigate potential irrigated agriculture water shortages (Reservoir Model Output: Release, diversion, and Shortages). The Reservoir Model component also contains a page (Reservoir Output: Storage and Flow Accumulations) where USGS stream data are used to calculate a variety of categories of yearly accumulations of water and to predict Nambe Pueblo Storage Allocation using USGS pre dam stream gage data and releases.

Calculations for both of the reservoir pages are based on the calibrated reservoir model. This model is was calibrated using coincident USGS inflow and outflow stream gauge data.

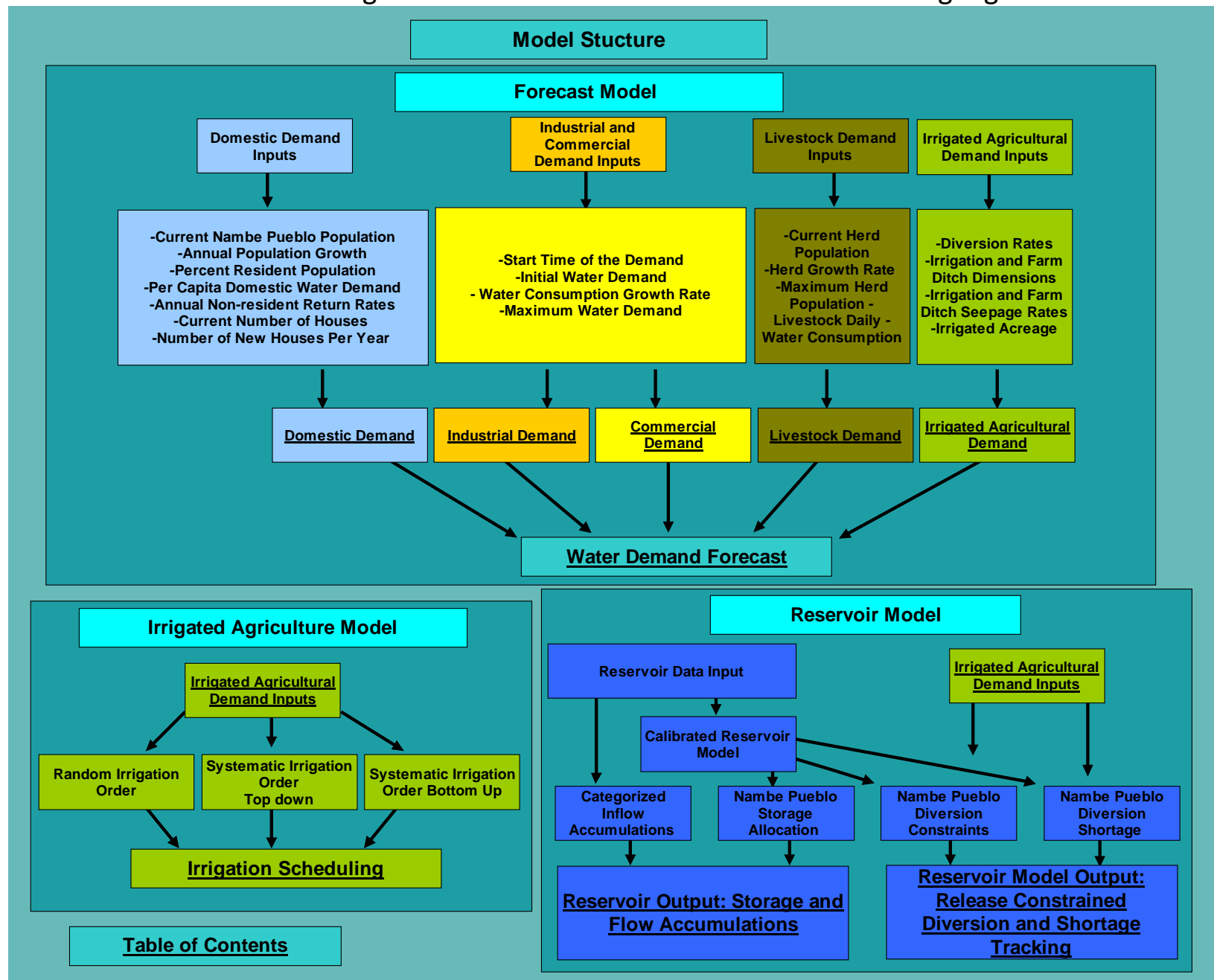

Figure 0-1: Screen shot of the Model Structure page. This graphic shows the three model components and identifies relationship between the input and output pages. The large boxes in the Forecast Model section lists the user input for that component 


\section{Water Demand Forecast Component}

\section{Background}

The Water Demand Forecast output page (Figure 0-1) has the hyperlinks to the Domestic, Industrial, Commercial, Livestock and Irrigation Demand user input pages and a time series plot versus Yearly Water Diversion for each of these categories of water use. A plot is also provided showing the sum of these categories. The first four of these water use categories are described in this section while the Irrigated Agriculture Demand component (seen as the "Irrigation Demand" link in Figure $0-1$ ) is described in its own section because the agriculture component has many options for user inputs that allow for investigation of irrigation efficiency improvements and because results from this component are also used in Reservoir Model component to calculate water shortages. User input for each of the categories is described next starting with the Domestic Demand user input page.

\section{Water Demand Forecast}

Nambe Pueblo forcased water demand calculations are based the user settings that are accessed by clicking on each of the five hyperlinks located below this frame. The user can go to each of the pages and adjust the settings for Domestic, Industrial, Commercial, Livestock, and Irrigated Agriculture Demand and return to this page and run the model to view projected Nambe Pueblo water demand.

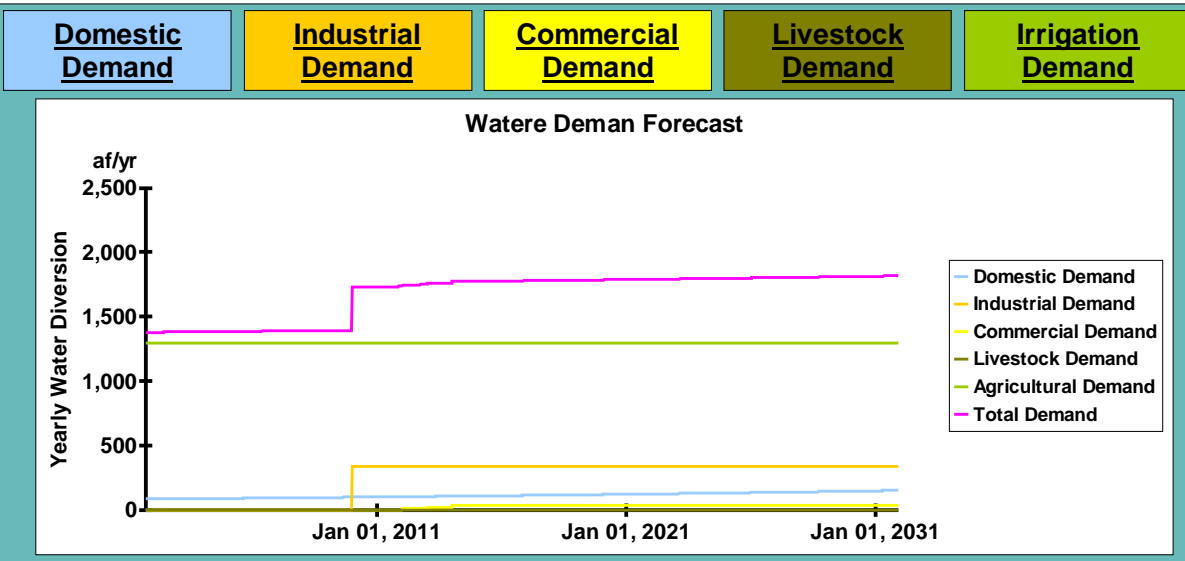

Nambe Pueblo Water Rights:

First Priority Existing Use - 522 af

First Priority Future Use -937 af

Federal Reserve Right - 302 af (Nambe Pueblo will recieve a one time payment for use of this water in the Regional Water System and will receive the Acquired Water Right)

Acquired Water Right -375 af

Economic Development Right - 131.25 af (Traded Pro Rata for Pojoaque Pueblo's share of Conservation Funds)

Total Useable Water Right $=1834$ af

Data Source: New Mexico ex rel State Engineer v. Aamodt, No 66cv06639 MV/LCS-ACE (D.N.M.) Settlement Agreement, Dated january 19, 2006 , Page 7 to page 16 .

\section{$\underline{\text { Table of Contents }}$ \\ Model Structure}

Figure 0-1: Screen shot of the Water Demand Forecast Page. The Water Demand Forecast output page showing the hyperlinks to the Domestic, Industrial, Commercial, Livestock and Irrigation Demand user input pages. The graph is a time series plot of the Yearly Water Diversion [af/yr] for each of the categories of usage and the sum of these categories. Brief instructions for using this page and a summary of Nambe Pueblo water rights (from New Mexico ex rel. State Engineer v. Aamodt, 2006) are included. 


\section{Domestic Demand}

The Domestic Demand page has user inputs, time independent calculated results based on the user inputs, and four time series plots (Figure 0-2). User inputs are through slider bars making up the left column on the page. The selected value is reported to the right of the slider bar. The time independent calculated results are located within the "Time Independent Results" text box. The time series plots include the Required Domestic Diversion and three other plots that are of interest to Nambe Pueblo: Nambe Pueblo Population, Number of Houses, and Persons per House. Nambe Pueblo forecasted population is calculated using Equation 0-1: Equation 0-1: 'Future Population'*'Population Growth Rate Annual'/365 da.

In this equation, Future Population is the Initial Population + the population from the previous time step. Population Growth Rate Annual is the user specified population growth rate, and $365<<d a>>$ is the number of days in a year. The Future Population variable is divided into two population categories, those living on the Nambe Pueblo lands (residents) and those living off of Nambe Pueblo lands (non-residents). The non-resident population growth is calculated using the same population growth equation as that given in Equation 1. All other calculations involve simple divisions or multiplications of the user input variables.

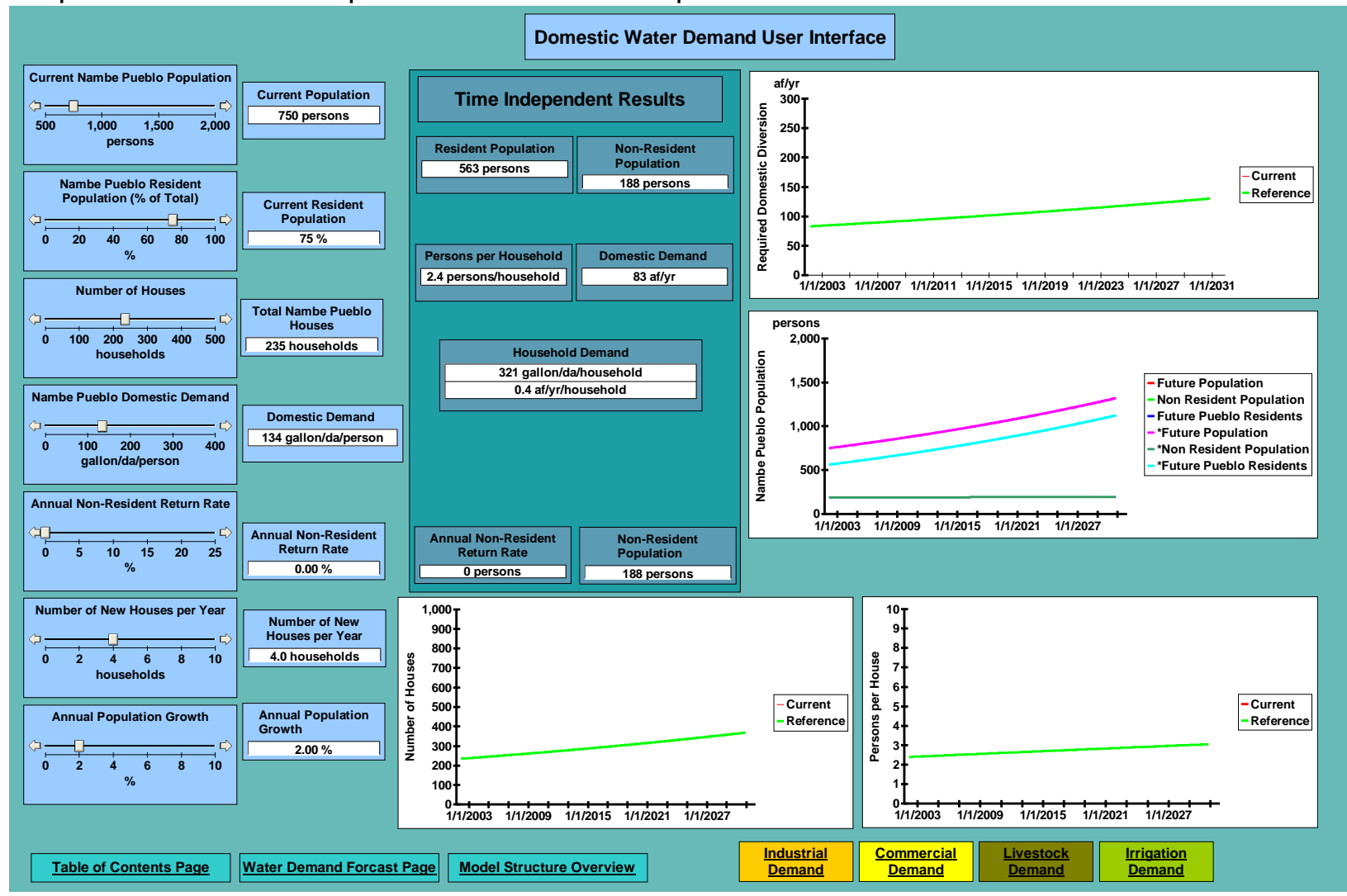

Figure 0-2: Screen shot of the Domestic Water Demand User Interface. The slider bars allow the user to adjust variables that impact time independent calculated results that change as the slider bars are adjusted, and time series graphs that are plotted as the program is ran. The user can save previous runs, change the variables through the slider bars, rerun the program and compare results between the two runs (see the Simulation Procedure Section for more information). 


\section{Industrial, Commercial, and Livestock Demand}

Industrial, Commercial, and Livestock Demand are discussed together in this section as the Industrial (Figure 0-3) and Commercial (Figure 0-4) Demand user interfaces have the essentially the same user input variables; that is Start Dates, Initial Water Demand, Expected Growth rates, and Maximum Water Demand; while the Livestock (Figure 0-5) interface is based on herd populations, growth rates and daily water consumption per animal. Unlike the Domestic Demand user interface, the Industrial, Commercial, and Livestock Demand user interfaces have only input slider bars; the output from these pages are reported in the Water Demand Forecast time series plot. The user selected value for each of the user selected variables is displayed in numerical form below each slider bar.

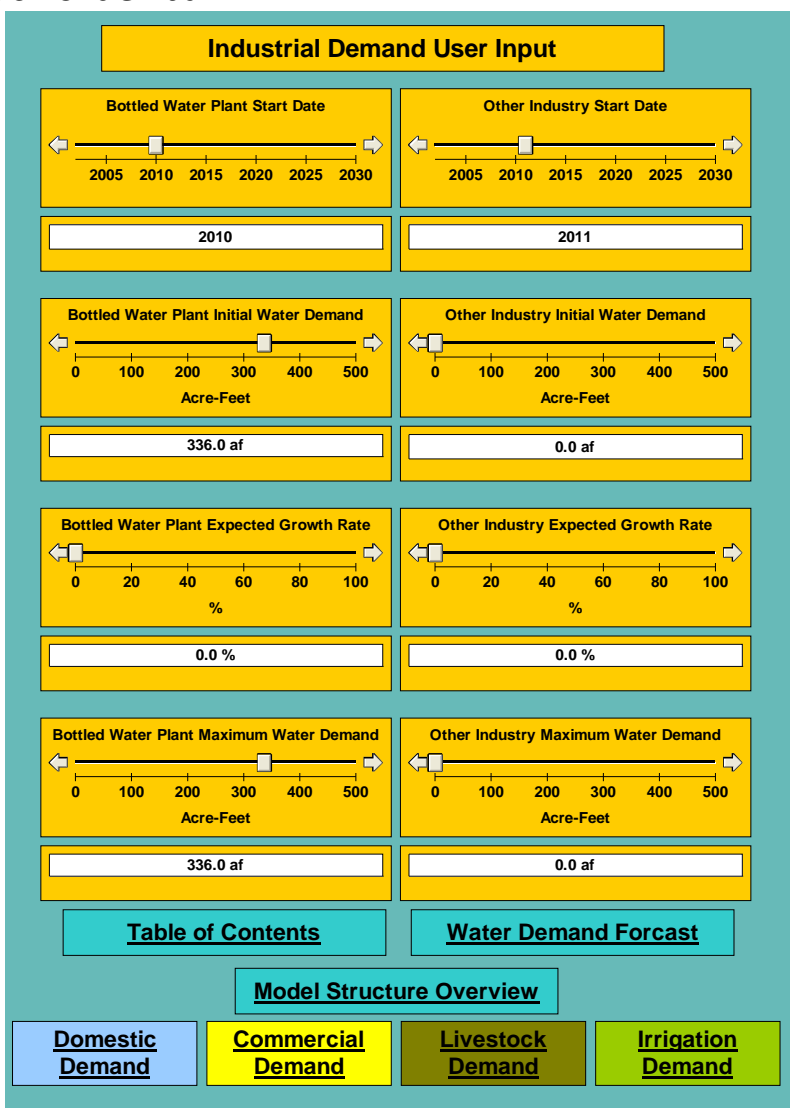

Figure 0-3: Screen shot of the Industrial Demand user interface. The user has the option to input expected start dates, the initial water demand, expected growth rates and maximum water demand. Calculated results from these settings are reported in the water demand time series plot on the used in the Water Demand Forecast page and are summed with the other categories of water demand to obtain current and forecasted total water demand for Nambe Pueblo. 


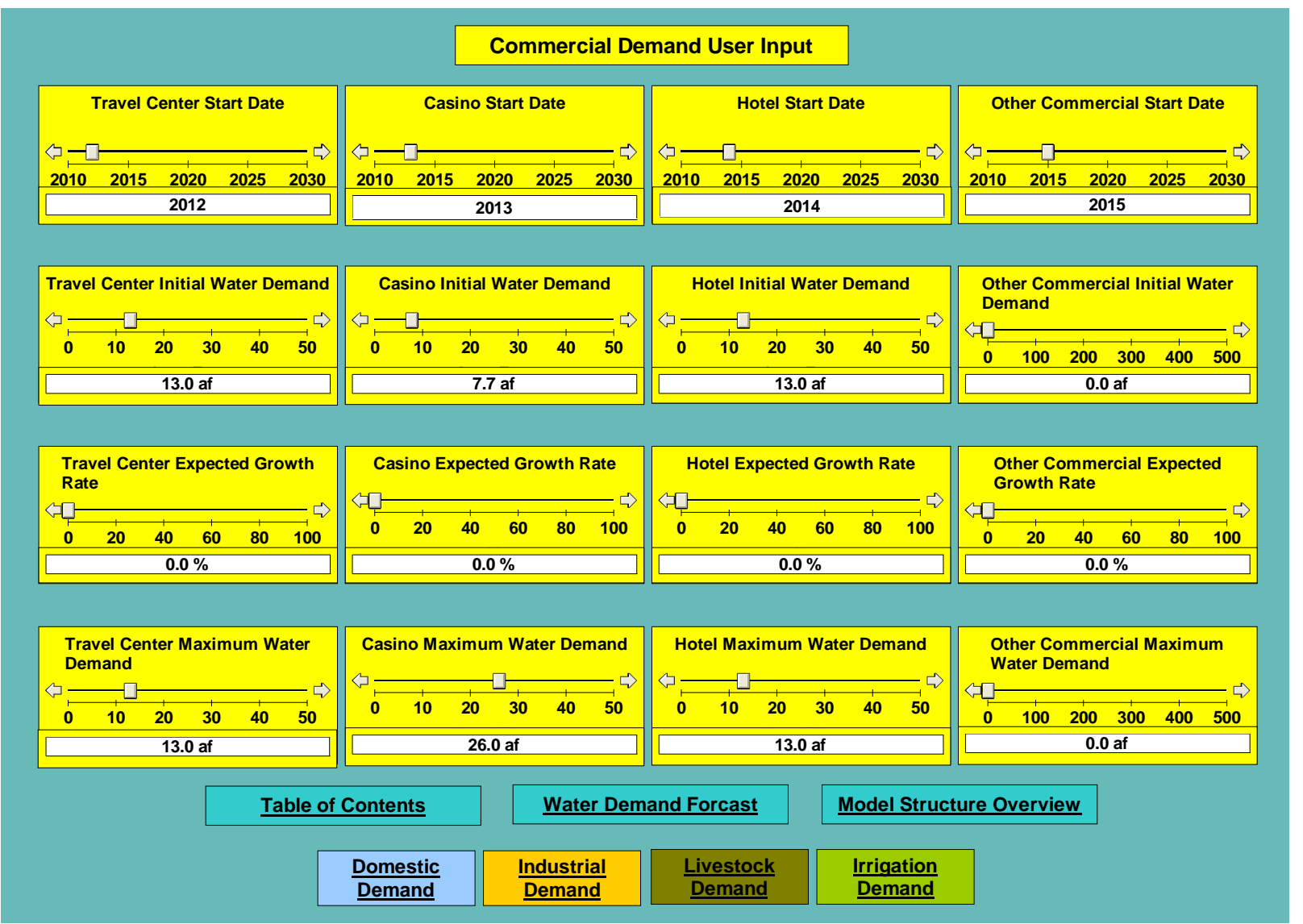

Figure 0-4: Screen shot of the Commercial Demand user interface. The user has the option to input expected start dates, the initial water demand, expected growth rates and maximum water demand. Calculated results from these settings are reported in the water demand time series plot on the used in the Water Demand Forecast page and are summed with the other categories of water demand to obtain the current and forecasted total water demand for Nambe Pueblo. 


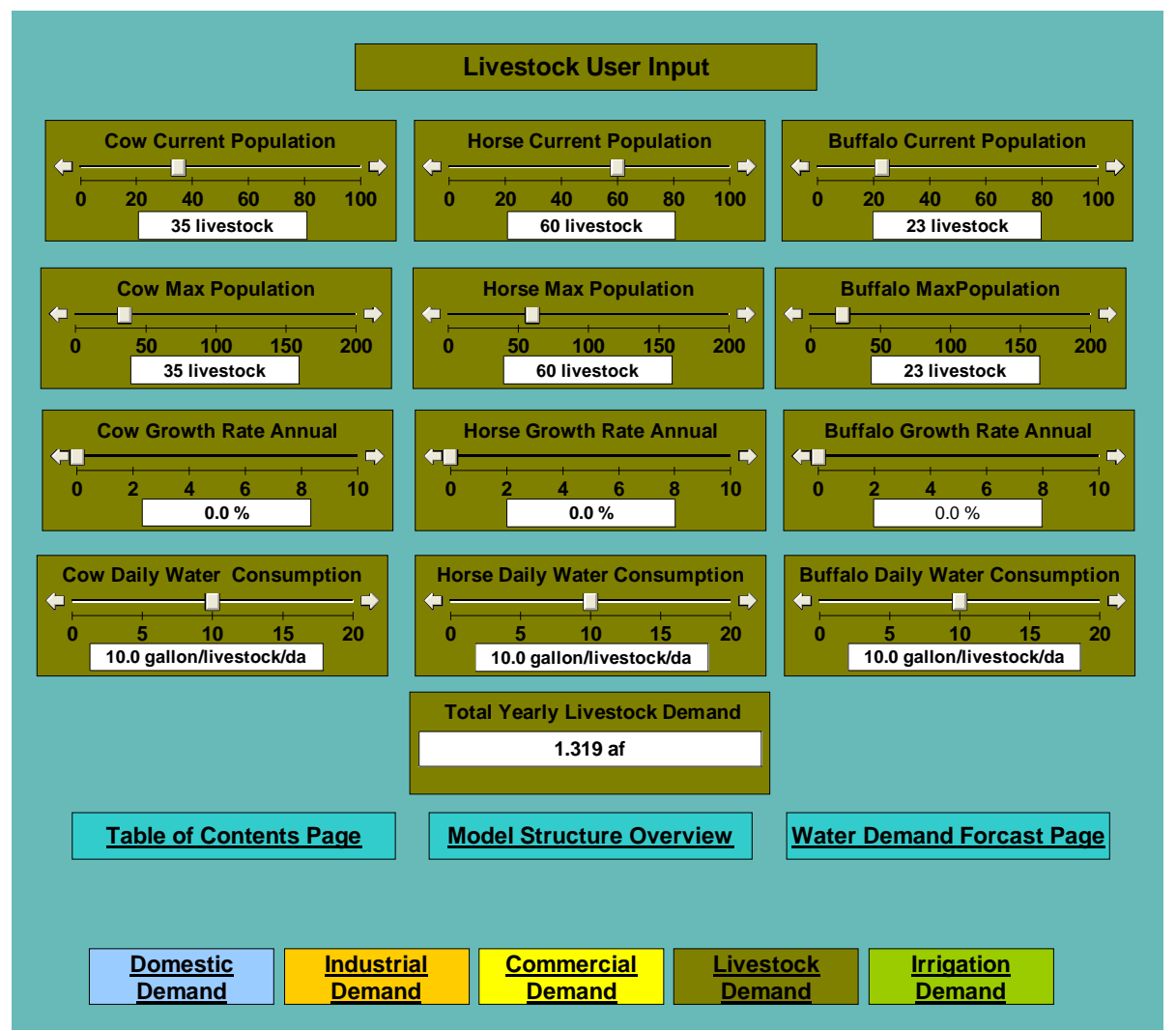

Figure 0-5: Screen shot of the Livestock Demand user interface. The user has the option to input current and maximum heard size, heard annual growth rate, and daily water consumption for three types of livestock. Calculated results from these settings are reported in the water demand time series plot on the Water Demand Forecast page and are summed with the other categories of water demand to obtain the current and forecasted total water demand for Nambe Pueblo. 


\section{Irrigated Agriculture Component}

The Irrigated Agriculture component of the model feeds results to the Water Demand and the Reservoir model components and provides the user with numerous inputs to investigate impacts of potential improvements in irrigation efficiency on the total required diversion from the Rio Nambe. This model component is strictly time independent so that the model does not have to be "ran" to see the results, rather the results are calculated and displayed as the input variables are altered.

\section{Irrigated Agricultural System Description}

Nambe Pueblo has two main irrigation ditches, the Highline and the Consolidated as illustrated in USGS Digital Orthophoto Quadrangle based areal photo map in Figure 0-1. Drawn on the map are traces of the Rio Nambe, the Consolidated and Highline ditches and the Nambe Pueblo irrigated lands. The caption describes the figure in detail.

Both the Highline and Consolidated ditches divert water from the Rio Nambe through substantial concrete structures and low head concrete dams. Each ditch has a Parshall flume in close proximity to the diversion and both ditches are concrete lined in the upper reaches of the ditches. In general the concrete ditches are in good condition; however fractures and displacements due to the close proximity of trees and other substantial vegetation are common.

\section{Irrigation System Model and Data Description}

The Irrigated Agriculture component of the model is built on information from field surveys; a scaled areal photograph; Interviews with Herbert Yeats, tour of Nambe Pueblo by Benjamin Yeats; and a GIS map provided by the Bureau of Indian Affairs. This information was compiled to derive critical irrigation system measures such as farm acreages, farm ditch locations, farm head gate locations, ditch construction types, condition of the ditches and ditch widths. Note that for the purposes of this model, Irrigation ditches are defined as the ditches which supply water to the farm head gates and the farm ditches are defined as the ditches that carry water from the head gate to each of the farms.

The model calculates seepage and evaporation rates for each section of irrigation ditch located between the farm head gates and for each farm ditch, and for all farm ditches feeding off of each irrigation ditch. The seepage rates are dependent on user selected seepage per unit area and ditch dimensions (width and depth) for each irrigation ditch section The seepage rates are subtracted from the user selected River Diversion Rate to give a delivery rate at each farm head gate along the irrigation ditch. Seepage and evaporation rates of each farm ditch are subtracted from the farm head gate delivery rate to obtain a delivery rate at each irrigated field. Finally a user selected Consumptive Irrigation Requirement Plus Field Loss (CIR+FL) rate is added to the irrigation and farm ditch losses for all farms on each irrigation ditch to give the total required farm irrigation rate for each farm. The $\mathrm{CIR}+\mathrm{FL}$ is also multiplied by the acreage of each farm to obtain the total required delivery for the irrigation season for each farm. The total required delivery is then divided by the farm delivery rate to obtain the required days to deliver the CIR+FL. 
The model default ditch dimensions are based on field measurements of width and depths of water in the ditches with the river diversion at $6 \mathrm{cfs}$ as measured at the Parshall flumes close to the river diversion location.

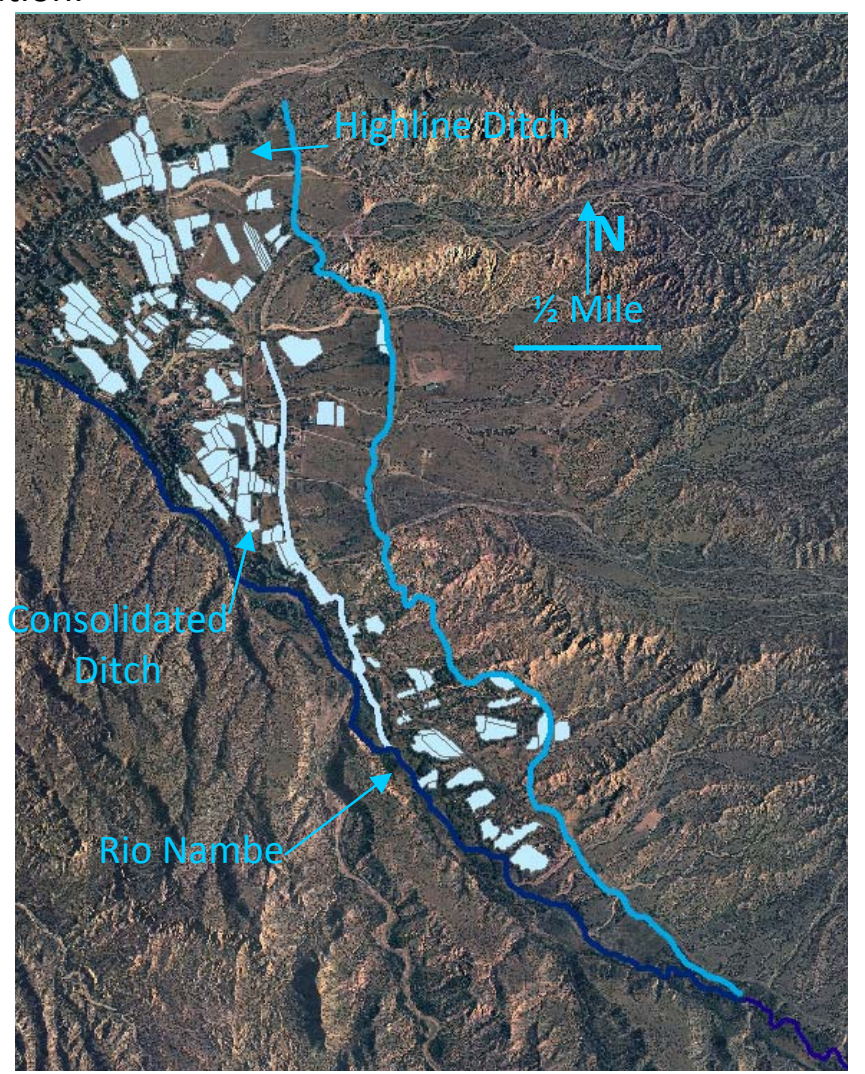

Figure 0-1: Areal photograph (USGS Digital Orthophoto Quadrangle based map) showing the Rio Nambe, the Highline and Consolidated irrigation ditches, and irrigated farms within the Nambe Pueblo lands. The dark blue line running diagonally across from the lower left (southeast) to the upper right (northwest) corner of the map and below all other added in features in the areal photo is the Rio Nambe, the other two blue lines are irrigation ditches and the two dimensional shapes are Nambe Pueblo irrigated fields. Other fields not marked on the map are non-Indian fields. The Rio Nambe and the irrigation ditches flow from the southeast to the northwest. The light blue line traces the consolidated ditch from the river diversion point to where it ends. Three other ditches branch off from the Consolidated ditch at its ending point on the map and continue in a north northwestern direction. These branches are not shown on the map. They irrigate fields to the left and in the upwards direction from the end of the Consolidated ditch. These ditches continue downstream to irrigate non-Indian fields. The abbreviated names of these three ditches are the Nueva, Llano, and Comunidad. The Highline ditch is traced with the bright blue line from its diversion point to its end. The irrigable land northwest of the Rio Nambe gently slopes to the southwest. Therefore the Highline, Consolidated, Nueve, Llano, and Comunidad ditches feed water to farms to the left of the ditches.

Approximate ditch lengths were obtained from a scaled areal photograph provided by Benjamin Yeats on which locations of farm head gates, farm irrigation ditches, and irrigated farms were plotted by Herbert Yeats. This areal photograph originated from the BIA and is likely based on digital areal photographs available through Santa Fe County. The areal photograph has higher resolution then the USGS Digital Orthophoto Quadrangle based maps. The BIA map was used to construct the schematic of the Nambe Pueblo irrigation system in Figure 0-2 (see the figure caption for a detailed description of the schematic map). The nomenclature on this map was 
used in the model as variable names. The Chili Line ditch which, because of its complexity and close proximity of farms on this ditch, was treated as a series of farm irrigation ditches.

Ditch loss calculations are common to many of the calculations that result in interface output in the Irrigated Agricultural component of the model. The model calculates ditch loss as a function of evaporation from the air/water interface surface area and seepage as a function of water/ground interface area.

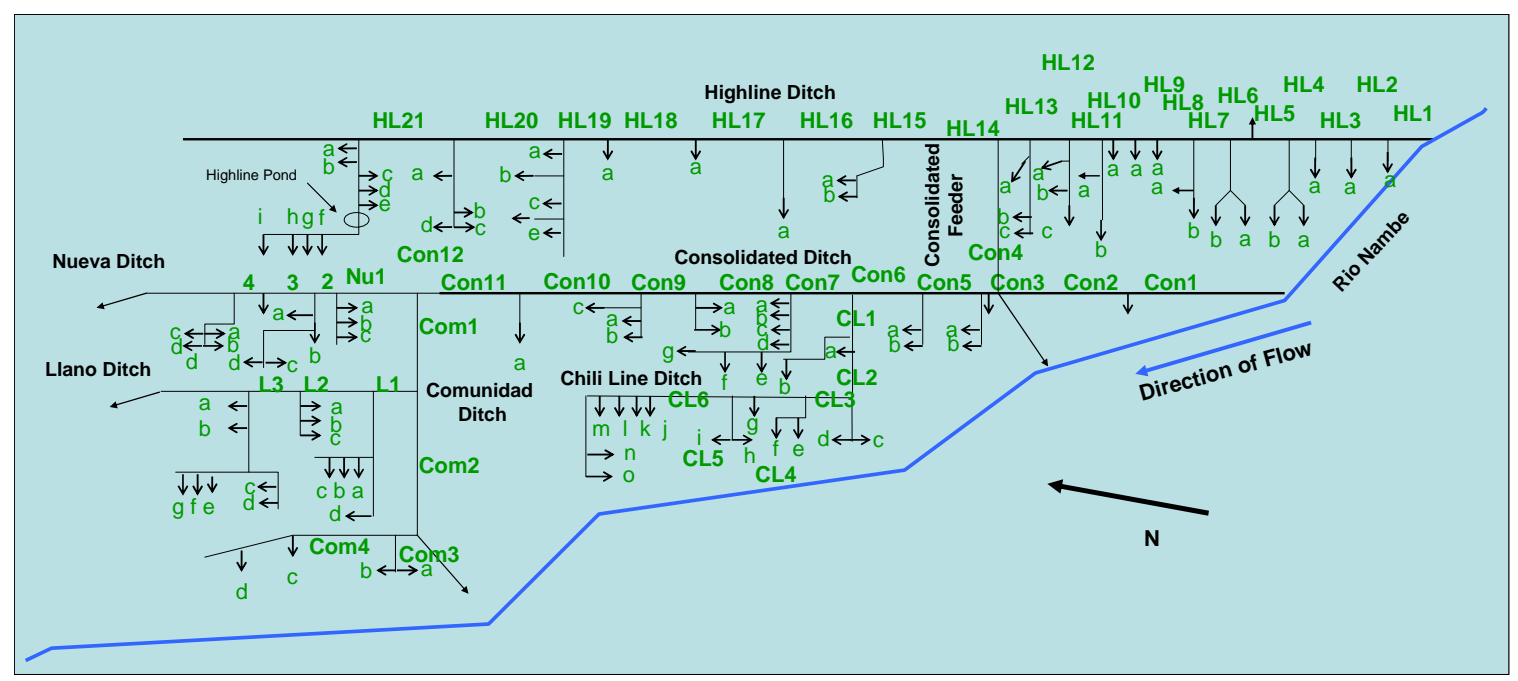

Figure 0-2: Schematic of the Nambe Pueblo Irrigation system. This schematic was constructed from information provided by Herbert Yeats on the scaled areal photograph discussed above. The schematic shows all the ditches discussed in the Irrigation Ditch Loss Calculations. The schematic shows the two major ditches on Nambe Pueblo, the Highline and Consolidated. These ditches are seen as straight horizontal lines starting at the Rio Nambe in the upper right of the schematic. Sections of the Highline and Consolidated ditch lay between the farm ditches seen as lines at $\mathbf{9 0}$ degrees to the horizontal Highline and Consolidated ditch lines. At the end of the farm ditch lines are arrows indicating the presence of irrigated fields. Each section of the Highline and Consolidated ditch are assigned a identifier. (Highline $=\mathrm{HL}^{* *}$, Consolidated $=$ Con ${ }^{* *}$ ) Also shown in the schematic is the Nueve, Llano, Comunidad, (left lower corner of the schematic at the end of the Consolidated ditch), and the Chili Line (center of the schematic emanating from the Consolidated ditch).

Ditch evaporation is calculated from evapotranspiration (ET) rates calculated with the Hargreaves' Equation (Hargreaves, 1975) and converted to open water evaporation rates. The development of the conversion involved selecting a monthly ET coefficient that reproduced the measured monthly open water evaporation rate at Nambe Reservoir. Minimum and maximum daily temperature data required by the Hargreaves' Equation came from the NOAA Satellite and Information Service (see reverences for full citation) and Nambe Reservoir Evaporation Data Came from the US Bureau of Reclamation (USBR) Nambe Reservoir Evaporation data (USBR 2001 to 2006). See Appendix A for details on the Hargreaves's Equation.

Seepage rates are calculated using per unit area irrigation ditch seepage rates for typical soils in Northern New Mexico published by the USDA (2001). For this calculation, all ditches were assumed to have vertical sides (see Appendix B for seepage loss calculation details.

The seepage rate calculations essentially involve multiplication of the ditch wetted perimeter by the length of the ditch and the seepage rate specified by the user. The use of flow rate versus wetted perimeter rating curves would be ideal to use for this calculation. These curves could be developed through measurements at points along the ditch at different diversion 
rates, or they could be estimated using the Manning's equation, an empirically derived formula relating flow velocity to channel depth, width, and channel roughness and slope. Unfortunately the data required for accurate implementation of one or the other of these approaches does not exist and the resources required to obtain the measured field data are not available. In the absence of the required measured data as discussed above, a simple approach was used to alter calculated seepage rates as a function of user input diversion rates. This method involves multiplication of calculated seepage by the ratio of the user specified diversion rate to $6 \mathrm{cfs}$ diversion rate under which measured depths and water surface widths were obtained. Certainly this method introduces error in the calculation of the seepage rates; however it constrains seepage in a consistent manner with regards to the diversion rate and prevents extreme over estimation of seepage at low diversion rates that result in negative flow values at head gates.

Because of the numerous user input options, the Irrigated Agricultural Demand Component has its own table of contents (Figure 0-3) where links to ten pages provide access to the following user adjustable irrigation related variables. Descriptions and method used to calculate these variables are described in the next section.

\section{Irrigated Agriculture User Interface Description}

The Irrigated Agriculture User Interface consists of a table of contents (Figure 0-3) and ten pages of interface. Each of the ten pages has different user selected inputs on the upper half of the page and the same output in the form of dials and bar plots on the lower half of the page (Figure 0-4). This split interface arrangement allows for efficient observation of calculated results as the input variables are manipulated. Also on the interface pages are text boxes with information relevant to the inputs and, in some cases user input dependent calculated results unique to each page.

Because of the numerous user input options, the Irrigated Agricultural Demand Component has its own table of contents where links to ten pages provide access to user adjustable irrigation related variables. Descriptions of these variables are described below in the page 1 to page 10 order depicted in hyperlinked text boxes in the table of contents.

Page 1: Diversion Rate and Consumptive Irrigation Requirement

- Page 1 User Inputs

o Highline and Consolidated Ditch Diversion Rates - these sliders determine the rate at which water is diverted from the Rio Nambe in cubic feet per second (cfs)

o Consumptive Irrigation Requirement plus Field Losses - these sliders determine the consumptive irrigation requirement $(\mathrm{CIR})$ plus field losses for farms on each of the five irrigation ditches. The CIR is that portion of water that is lost to evapotranspiration and the field losses account for inefficiencies in the field delivery of water.

- Page 1 Outputs - note that the "map" text box is a hyperlink an areal photograph that has the associated farmed fields indexed to each bar on the bar plots. The acreage can also be adjusted from this map and the bar graph at the top of the map because this map is shared with Pages 9 and 10 where the irrigated acreage can be adjusted. 
o Required River Diversion - the total amount of diversion from the Rio Nambe to satisfy the required total irrigation demand for one irrigation season.

o Required Farm Diversion - the total amount of diversion from the Rio Nambe to satisfy the total farm demand for one irrigation season.

o Required Irrigation Days - the total number of days required to meet the total irrigation demand.

o Irrigation Ditch Loss - the total irrigation ditch loss (seepage + evaporation) during the number Required Irrigation Days.

o Farm Ditch Loss - the total irrigation ditch loss (seepage + evaporation) during the number Required Irrigation Days.

o Total Required Irrigation Days for Each Farm and Farm Acreage - these bar plots show the breakdown of day required to irrigate farms on each of the five ditches and the number of associated acres for each farm.

o Total Required Irrigation Demand for Each Farm - these bar plots give a breakdown of the irrigation demand for each farm,

- Page 1 Information Boxes

o Maximum Allowed Diversion per Irrigation Season - the column with the header titled "Flow (cfs)" is the required diversion rate over the 184 day irrigation season that is required to satisfy the quantity of water in the "Allotted (af/ac/IrrSeas)" for each of the three diversion locations indicated in the first column. The "Allotted" values and the diversion locations are stipulated diversions given in the Aamodt settlement as stated in Section 5.1.3 on page 32:

"For agricultural uses the diversion amount shall not exceed 4.65 AFY per acre diverted by the ditch at the point of diversion from the surface source of water, 3.35 AFY per acre delivered at the farm head gate or well head, or a consumptive irrigation requirement of 1.84 AFY per acre, whichever is less."

The column with the "Actual (af/ac/IrrSeas)" is the diversion from the Rio Nambe that is required to satisfy the allotted diversion given the number of acres selected by the user on pages 9 and 10 of this interface sequence of pages.

Efficiencies - The efficiency ratings in the column with the header titled "Calculated" are calculated from the model results and change as the user selects different inputs while the "Target" column values were calculated from the values given in the "allotted" column in the "Maximum Allowed Diversion per Irrigation Season" text box. Ditch Efficiency is the Farm Diversion Divided by the Project diversion, the Farm Efficiency is the CIR divided by the Farm Diversion, and the Project Efficiency is the product of the Ditch Efficiency and Farm Efficiency. Page 2: Highline Ditch Dimensions

Page 2 User Inputs

Highline Irrigation Ditch Water Line Width and Water Depth - the two bar graphs have "grab points" that allow the user to adjust the widths and depths of the Highline irrigation ditch. Numerical values can also be entered in the number fields below each field. The "map" text box is a hyperlink to an associated areal photograph locating the ditch section using the nomenclature for each ditch section found at the base of each bar of the bar graph. The acreage can also be adjusted from this map through bar graph at the top of the map because 
this map is shared with Pages 9 where the irrigated acreage can be adjusted. Any one of the ten Irrigated Agriculture component pages can be access through the hyperlinked text boxes.

Page 2 Outputs

See Page 1 Output

Page 2 Information Box

See the Efficiencies bullet under Page 1 Information Box

Page 3: Consolidated Irrigation Ditch Dimensions

Page 3 User Inputs

Consolidated Irrigation Ditch Water Line Width and Water Depth -See Page 2 User Inputs

Page 3 Outputs

See Page 1 Output

Page 3 Information Box

See the Efficiencies bullet under Page 1 Information Box

Page 4: Nueva, Llano and Comunidad Irrigation Ditch Dimensions

Page 4 User Inputs

Consolidated Irrigation Ditch Water Line Width and Water Depth. See Page 2 User Inputs

Page 4 Outputs

See Page 1 Output

Page 4 Information Box

See the Efficiencies bullet under Page 1 Information Box

Page 5: Farm ditch dimension for all farm ditches

Page 5 User Inputs

Farm Ditch Water Surface Width and Water Depth - The farm ditch dimensions are adjusted in groups according to the irrigation ditch from which they arise

Page 5 Outputs

See Page 1 Output

Page 5 Information Box

See the Efficiencies bullet under Page 1 Information Box

Page 6: Highline and Consolidated Irrigation Ditch Seepage

Page 6 User Inputs

Seepage for Highline and Consolidated Irrigation Ditch - See Page 2 User Inputs

Page 6 Outputs

See Page 1 Output

Page 6 Information Box

A table presents the seepage data for ditch types as a guide the user for specifying ditch seepage rates. The table is from a United States Department of Agriculture (USDA) technical note (2001).

See the Efficiencies bullet under Page 1 Information Box

Page 7: Nueva, Llano, Comunidad Irrigation Ditch Seepage

Page 7 User Inputs

Seepage Nueva, Llano, Comunidad Irrigation Ditch Seepage. See Page 2 User Inputs.

Page 7 Outputs

See Page 1 Output

Page 7 Information Box 
See page 7 Information Box

See the Efficiencies bullet under Page 1 Information Box

Page 8: Highline and Consolidated Farm Ditch Seepage

Page 8 User Inputs

Farm Ditch Seepage - the farm ditch Seepage is adjusted in groups according to the irrigation ditch from which they arise.

Page 7 Outputs

See Page 1 Output

Page 8 Information Box

See page 7 Information Box

See the Efficiencies bullet under Page 1 Information Box

Page 9: Highline and Consolidated Farm Acreage

Page 9 User Inputs

Acreage of Highline and Consolidated Ditch Farms - farm acreage bar graphs that can be adjusted through grab points or adjusted by changing the number at the base of each bar. The map text box is a hyperlink to an areal photograph where the number at the base of each bar is associated with a field on the photograph. The bar graph at the top of the page can also be adjusted.

Page 9 Outputs

See Page 1 Output

The total acreage is given

Page 9 Information Box

See the Efficiencies bullet under Page 1 Information Box

Page 10: Highline and Consolidated Farm Acreage

Page 10 User Inputs

See Page 9 User Inputs

Page 10 Outputs

See Page 1 Output

The total acreage is give

Page 10 Information Box

See the Efficiencies bullet under Page 1 Information Box 


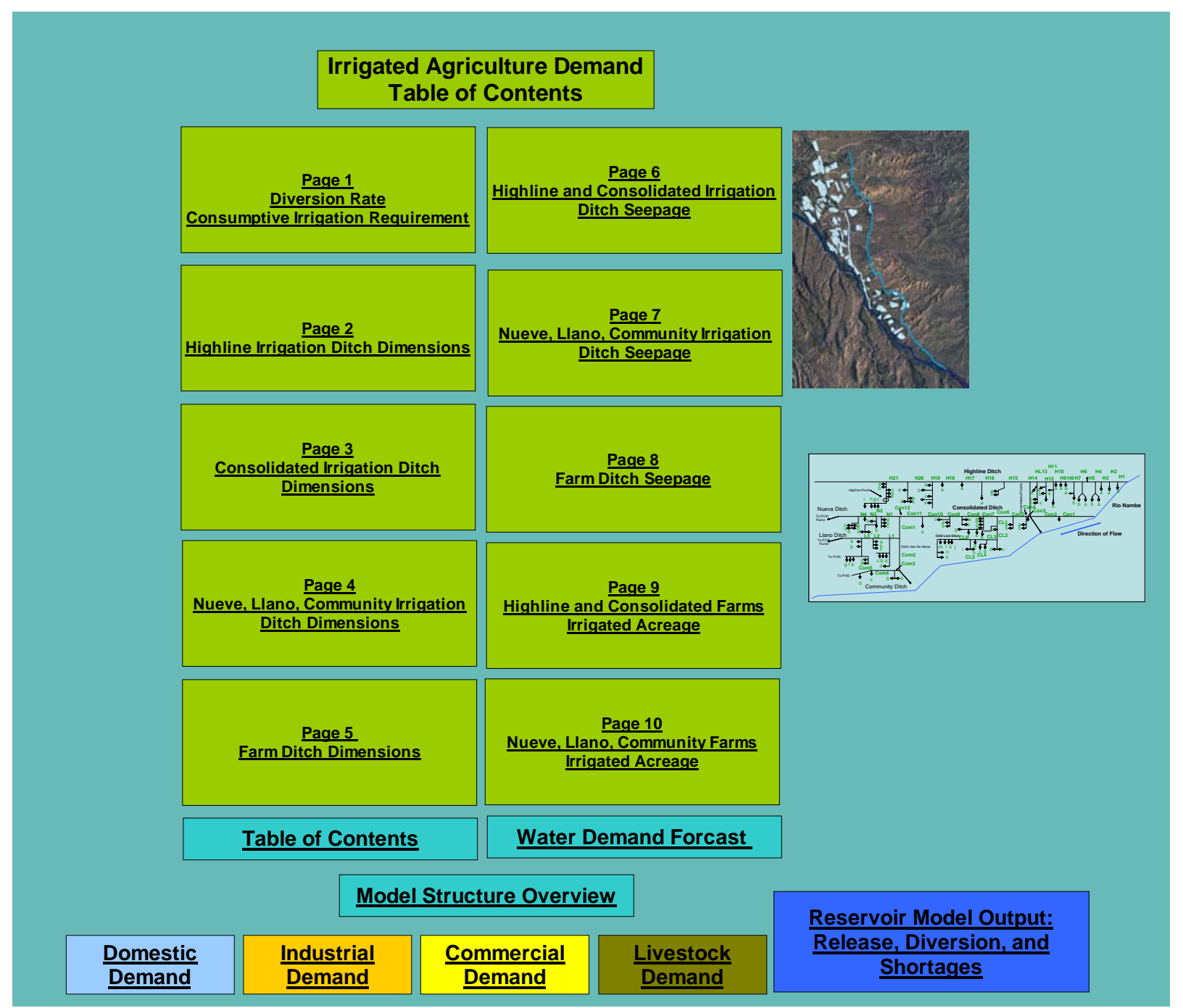

Figure 0-3: Screen shot of the Irrigated Agriculture Demand Table of Contents Page. This page has hyperlinked text boxes ten Irritated Agriculture component pages and to other pages that use input from this component. Two additional links lead to areal photograph showing the Nambe Pueblo irrigated fields and a schematic map used to track model nomenclature. 


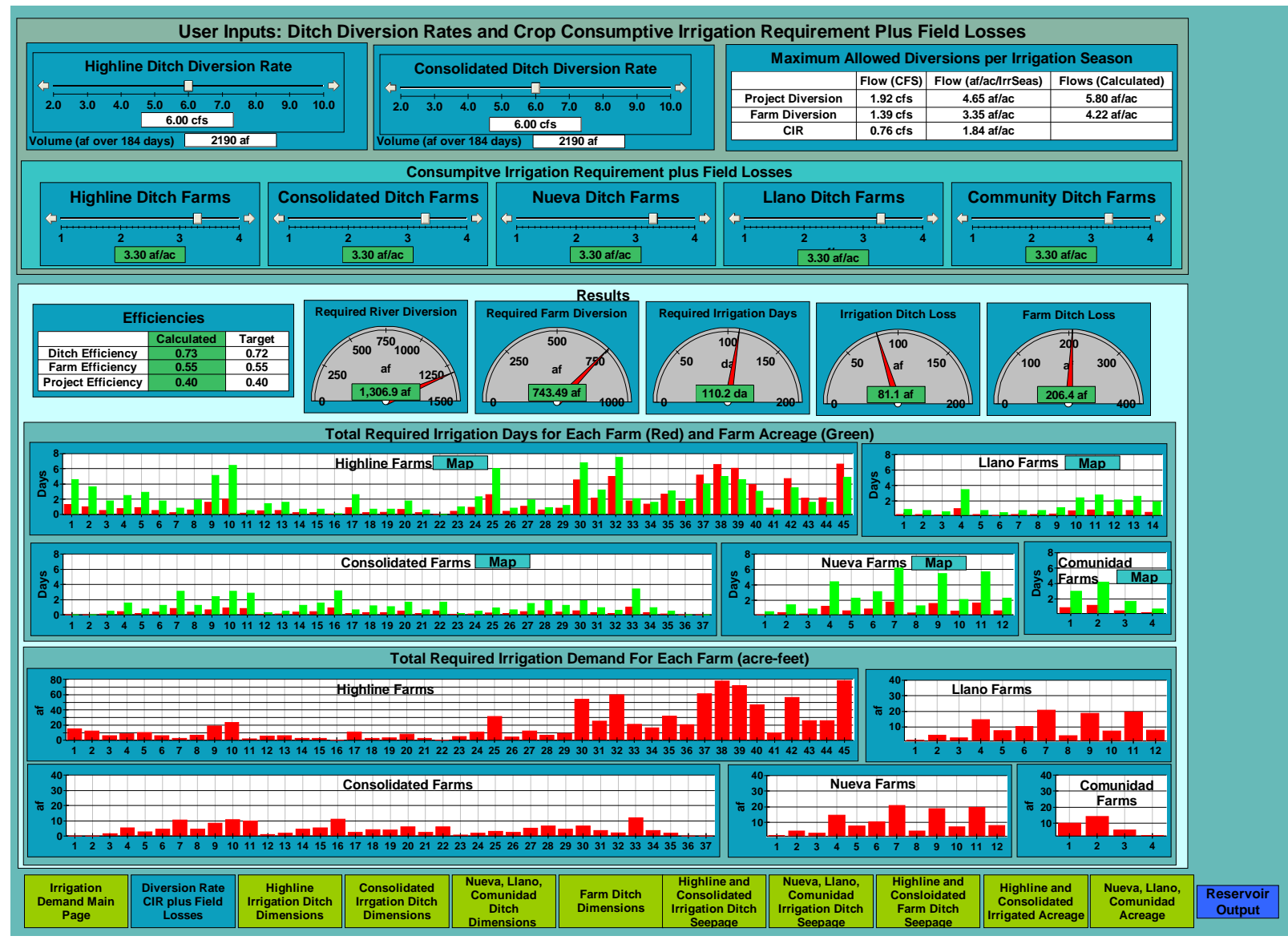

Figure 0-4: Screen shot of the first page of the Irrigated Agriculture component interface showing the user input slider in the upper half of the screen and the interface outputs in the lower half. The inputs are different for each of the ten pages while the output remains the same. Each of the slider bars have numerical reports indicating the value selected by the slider. Hyperlinks to annotated areal photos provide a quick reference for tying both input and output to specific field locations while a Reservoir Output hyperlink takes the user to the part of the Reservoir component that is dependent on the irrigated Agriculture component.

\section{Irrigation Scheduling}

The Irrigation Scheduling section of the model is based on the Irrigated Agriculture component and is independent of all other sections of the model. It was incorporated into the model to illustrate the potential savings by showing losses from the least, most and an intermediate efficient irrigation schedules for the Highline ditch. The three irrigation schedules are as follows: a random schedule where farms are irrigated in a random sequence (least efficient), a top down schedule where farms are irrigated in sequence starting with the farm at the top of the ditch (most efficient), and bottom up where the last farm on the ditch is irrigated first a followed by all other farms in sequence to the top of the ditch (intermediate efficient). The Irrigation Scheduling section does not have any user adjustable variables; however the results are impacted by the user adjustable variables in the Irrigated Agriculture component of the model. The output for the Irrigation Scheduling page is shown in Error! Reference source not 
found.. The simulation is ran over a 7 month interval starting March 1, and ending October 1, roughly corresponding with the irrigation season which actually starts on April 1.

The Irrigation Scheduling simulation tracks two aspects of seepage and evaporation, first they are tracked in the sections in which water is flowing to feed a particular farm ditch, second they are tracked for sections of ditch that experiences loss due to recession of water in the ditch when irrigation is switched from a farm lower on the irrigation ditch to another higher on the ditch. In the later case the modeled assumption is that all water is lost in the ditch to seepage or evaporation between the two farm ditches when recession occurs.

Three plots are presented in Figure 0-3, the upper is a time series of the cumulative irrigation ditch loss for three irrigation schedules over three irrigation events during the entire irrigation season, the middle plot is a bar plot showing the total ditch loss for each of the irrigation schedules, and the lower plot is also a bar plot showing the total seepage and evaporation for the part of the ditch that is feeding water to the farm ditches. The numerical value of each bar is reported above each of the bars.

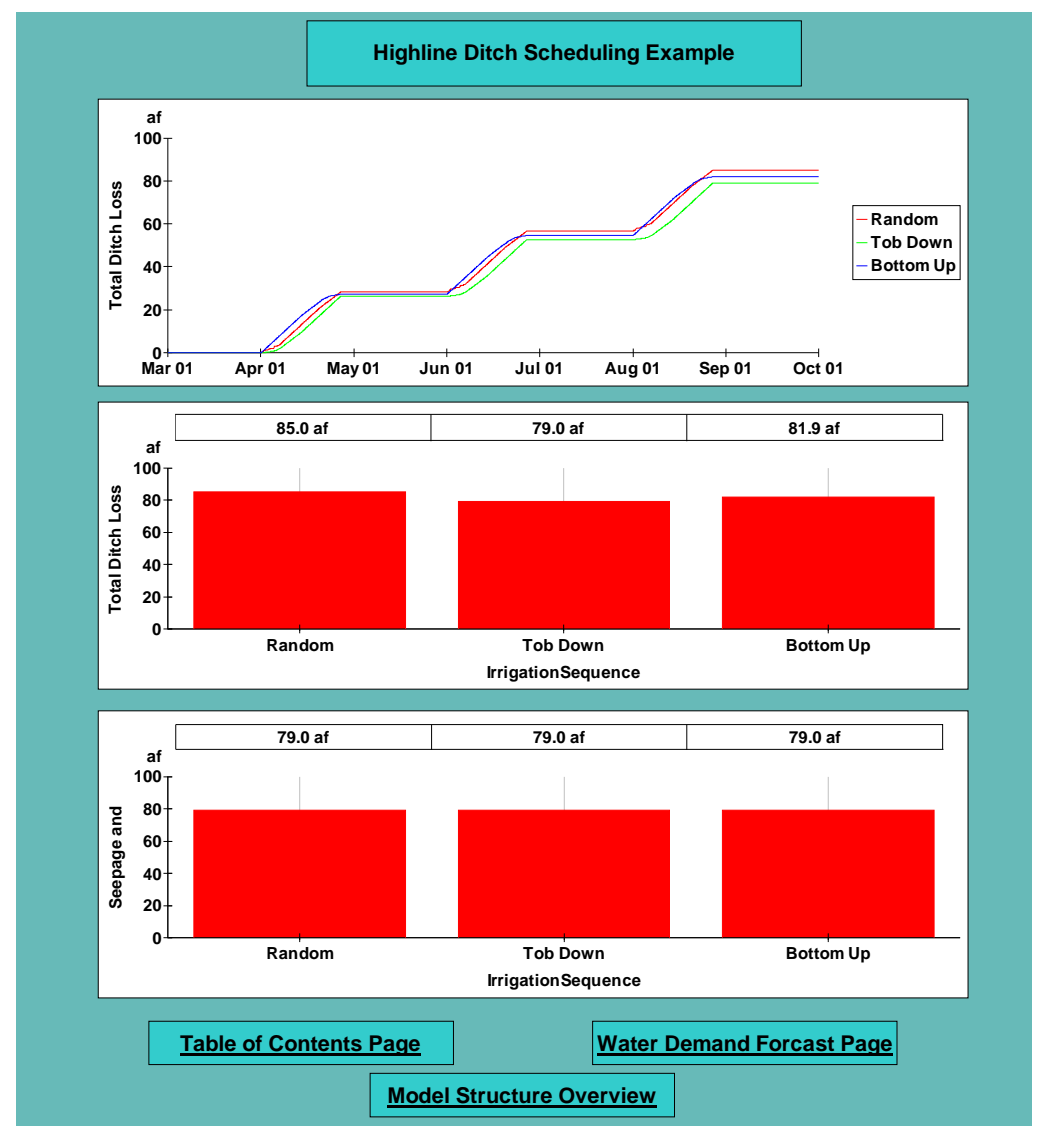

Figure 0-5: Screen shot of the Irrigation Scheduling output page. The three plots above provide the following information: the upper is a time series of the cumulative irrigation ditch loss for three irrigation schedules over three irrigation events during the entire irrigation season, the middle plot is a bar plot showing the total ditch loss for each of the irrigation schedules, and the lower plot is also a bar plot showing the total seepage and evaporation for the part of the ditch that is feeding water to the farm ditches. The numerical value of the each bar is reported above the bars. 


\section{Reservoir Model Component}

\section{Introduction}

The Reservoir Model Component serves several purposes in the Nambe Water Budget Model. First it provides estimates of Nambe Pueblo's storage allocation in the reservoir using historic USGS inflow data and pre-dam USGS Rio Nambe stream flow data which allows the user to gain a perspective on the reservoir storage available to Nambe Pueblo under a variety drought and non-drought conditions. Second, it tracks winter, summer, and total reservoir accumulations as well as those summer accumulations when the flows are above and below $10 \mathrm{cfs}$. Third, it is used to quantify irrigation shortages under a user selected diversion rates in the Irrigated Agriculture component of the model, and fourth to quantify the number of days the user selected diversion rates are not met. These three outputs are discussed in sections following a discussion on the calibrated reservoir model upon which the three components are built. In contrast to the other model components of the Nambe Pueblo model, Simulation start and stop times in the reservoir model are always set on a three year interval and the time step is over a 0.5 day period. This short simulation period and short time step results in detailed plots that allow for discrimination of time step scaled patterns.

The reservoir output sections of the Nambe Model undoubtedly require refinement because, in practice, reservoir releases do not follow a systematic schedule. Rather the releases are dependent on irrigation requirements that vary from week to week, month to month and year to year. Gaining an understanding of this process will involve input from all users and not just Nambe Pueblo. It is anticipated that this opportunity will occur as part of a continuing NMSBA project where the agriculture portion of the Nambe Reservoir model will be expanded down stream to all users of the Nambe Reservoir. The reservoir outputs in the current model are presented here as a primer for Nambe Pueblo to begin thinking about the larger problem of characterizing reservoir releases schedules in a meaningful and insightful manner while considering the type of output that would be useful not only to Nambe Pueblo, but all users of Nambe Reservoir Water.

A calibrated Nambe Reservoir model was built as part of this project to allow for investigation of storage and water availability over a broad range of drought and not-drought conditions. The calibrated reservoir model is used in all of the Reservoir component calculations.

\section{Reservoir Calibration}

Construction of the Nambe Reservoir calibrated model was a multi step process starting with performing water balance calculations using concurrent USGS inflow and outflow stream gage and USBR evaporation and precipitation data. Initially the calibration was refined for the time interval starting $10 / 30 / 2004$ and ending $12 / 31 / 2005$. This refined calibration model was then ran from 10/1/2001 to 12/31/2007 and additional calibration components added to improve replication of the historic storage data. This longer interval is the time during which the USGS stream gaging stations above and below the reservoir were operational. The calibration steps are summarized next. 
1) Perform water balance calculations limiting the simulation time to a one year period where operations are not influenced by drought or extremely wet conditions (10/30/2004 to $12 / 31 / 2005)$. Adjust the USGS inflow and outflow data such that the simulated pool storage matches storage derived from the USGS reservoir water surface elevation through the USBR elevation/capacity rating curve. The inflow factor is then used on subsequent calibrations and retain in the final calibrated model.

2) Incorporate a release schedule based on water supply outlook. The current storage is added to the estimated total runoff from the snow pack and the total is divided by 184 days of irrigation season starting April 1 and ending October 31. Off season releases are $1 \mathrm{cfs}$. Cumulative inflow plots during spring runoff (April 1 to July 1 ) roughly indicate runoff from snow melt. For the 2005 year, a wetter than average year, the inflow from snow melt was approximately 3 times the maximum storage of Nambe reservoir while for the 2002 year, a much dryer than average year, inflow from snow melt was $25 \%$ of the maximum capacity of the reservoir.

3) Add in off season release controls based on three possible reservoir storage intervals during the off season: storage less than 1000 af, storage greater than 1000 af and less than 1500 af, and storage greater than 1500 af. An inspection of historic reservoir releases versus reservoir storage during the last thirty years of operation shows that the following release schedule is usually followed: for storage less than 1000 af, release 1.3 cfs; for storage greater than 1000 af and less than 1500 af, release $1.3 \mathrm{cfs}$; and for storage greater than 1500 af, release $1.0 \mathrm{cfs}$. These release conditions are used in the calibrated model

4) Add in a reference ET dependent water release. Reference ET is calculated using the Hargreaves' equation described in Appendix A. This modification attenuates water demand, and therefore releases during the early spring and late summer when ET rates are low.

5) Add in a drought reduction factor to account for more conservative water releases during water shortage years. This addition became necessary when the simulation time was expanded to include all the years during which both the above and below reservoir USGS gaging data was available 10/1/2001 to 12/31/2007).

\section{Reservoir User inputs}

The reservoir outputs are based on the calibrated reservoir model. The user does not have any options for changing reservoir operation rules. Rather these rules were "hard wired" into the model through the calibration procedure.

In this section of the Nambe Pueblo Model, the user also has the option of selecting the input from eleven sets of three year interval stream flow data obtained from three USGS Rio Nambe gauging stations: the current station located above the reservoir (Rio Nambe above Nambe Reservoir USGS ID\# 8294195) 10/01/2001 to 1/1/2007), and two pre-dam stations located down stream from the Nambe Falls (Rio Nambe Near Nambe -USGS ID\# 8295000: 10/1/1939 to 9/30/1951 and Rio Nambe at Nambe Falls USGS ID\# 8294300: 10/1/1963 to 9/30/1978) combined to create input data for the reservoir spanning the interval from 10/01/2001 to 9/30/2034 over which the user has a choice of simulating over three year intervals starting with the 10/01/2001 date by selecting the time span in the "Water Year Switch" available on both 
pages containing the reservoir output (Figure 0-1and Figure 0-2). Below the switches are hyperlinks that take the user to a page containing a bar plot showing the cumulative stream flow for each of the water years starting October 10, 2001 (Water Year 2002) and ending September 30, 2034, and a series of three plots showing the stream flow for each of the eleven three year intervals given in the Water Year Switch (Figure 0-3). These plots give the user perspective on the water supply for the years selected for simulation.

\section{Reservoir Outputs}

The plots titled outputs titled "Nambe Pueblo Storage Estimates" and "Water Year Inflow Accumulation by Categories" are located on the same page so they are discussed together in the next section and the "Reservoir Release Constrained Diversion Rates" and "Number of Diversion Shortage Days" are discussed together in the last section.

\section{Nambe Pueblo Storage Estimates and Inflow Accumulation}

Estimates for Nambe Pueblo storage are based on the US Bureau of Reclamation water accounting process where reservoir losses (evaporation) are proportionally subtracted from each of the user's storage in the reservoir. Reservoir gains are divided among the users according to the percentage of gain each user is allowed. In this accounting scheme Nambe Pueblo receives $13.8 \%$ of the reservoir gains through out the year and, for the purpose of the storage estimates, Nambe Pueblo releases are $13.8 \%$ of the total releases from the reservoir. A sample simulation for the water years of 2002 through 2004 is presented in the upper graph in Figure 0-1Error! Reference source not found.

Accumulations by categories are presented in the lower plot in Figure 0-1Error! Reference source not found. The categories include all flow rates, summer flow rates up to 10 cubic feet per second (cfs) summer flow rates above $10 \mathrm{cfs}$., all summer flows, and all winter flows. The summer flow rates are significant because Nambe, San Ildefonso and Pojoaque Pueblos are allowed to store or use the natural flows up to $10 \mathrm{cfs}$ during the irrigation season.

\section{Reservoir Release, Diversion and Shortages}

The Reservoir Release Constrained Diversion Rates page also has two plots (Figure 0-2); the upper plot captures the impact of having inadequate reservoir releases on the required irrigation interval for three irrigation events during three irrigation seasons while the lower plot shows the accumulation of days that the desired diversion was not satisfied. For these simulations, the diversion rates were set at $6.0 \mathrm{cfs}$. The diversion rates are set in the "Diversion Rate CIR plus Field Losses" page of the Irrigated Agriculture Component. The Irrigation Agriculture Component calculates the time interval required to meet the irrigation demand for both the Highline and Consolidated ditch.

The lower plot tracks the accumulation of days during which time stream flows are less than the user set diversion for both the Highline and Consolidated irrigation ditches. In actuality, the model counts each time step during which the Rio Nambe flows are not adequate to meet the user set diversion rate.

In order for there to be no shortages, the Rio Nambe has to flow at $12 \mathrm{cfs}$ using the default settings of $6 \mathrm{cfs}$ for each ditch. The diversion for each of the two ditches can be changed on the 
"Diversion Rate CIR plus Field Losses" page of the irrigated agriculture component. Hyperlinks are provided to all of the pages of the Irrigated Agriculture component because changing the diversion rate, as well as many of the other user changeable variables in this component, impacts irrigation efficiency, and therefore impacts the required time to complete a round of irrigation.

On the Release Constrained diversion and Shortage Tracking page, the user has the option of altering five variables related to river flow that impact the results in the plots in Figure 0-2. These user changeable variables are the following: 1) required instream flow below the Highline ditch diversion, 2) required instream flow below the Consolidated ditch diversion, 3) Rio en Medio inflow factor, 4) Spring inflow above Highline, and 5) Spring Inflow above Consolidated. The required downstream flows below the Highline and Consolidated ditch diversions have been added to the model to account for required bypass at these irrigation ditch diversions. The two sliders that adjust Rio Nambe flows to account for spring fed contributions above each of the two diversions were added in recognition that this reach of the Rio Nambe is a gaining reach as evidenced by the observable springs. The Rio en Medio inflow factor accounts for additional flow added to the Rio Nambe below the Highline diversion and above the Consolidated diversion. This tributary contributes about $1 / 3$ of the natural Rio Nambe flow to the Rio Nambe (Jack Veenhuis, Personal communication, Feb 2007). Inflows into the Nambe Reservoir are multiplied by this factor and added to the Rio Nambe flows below the Highline diversion. The default setting for this inflow is 0.3 .

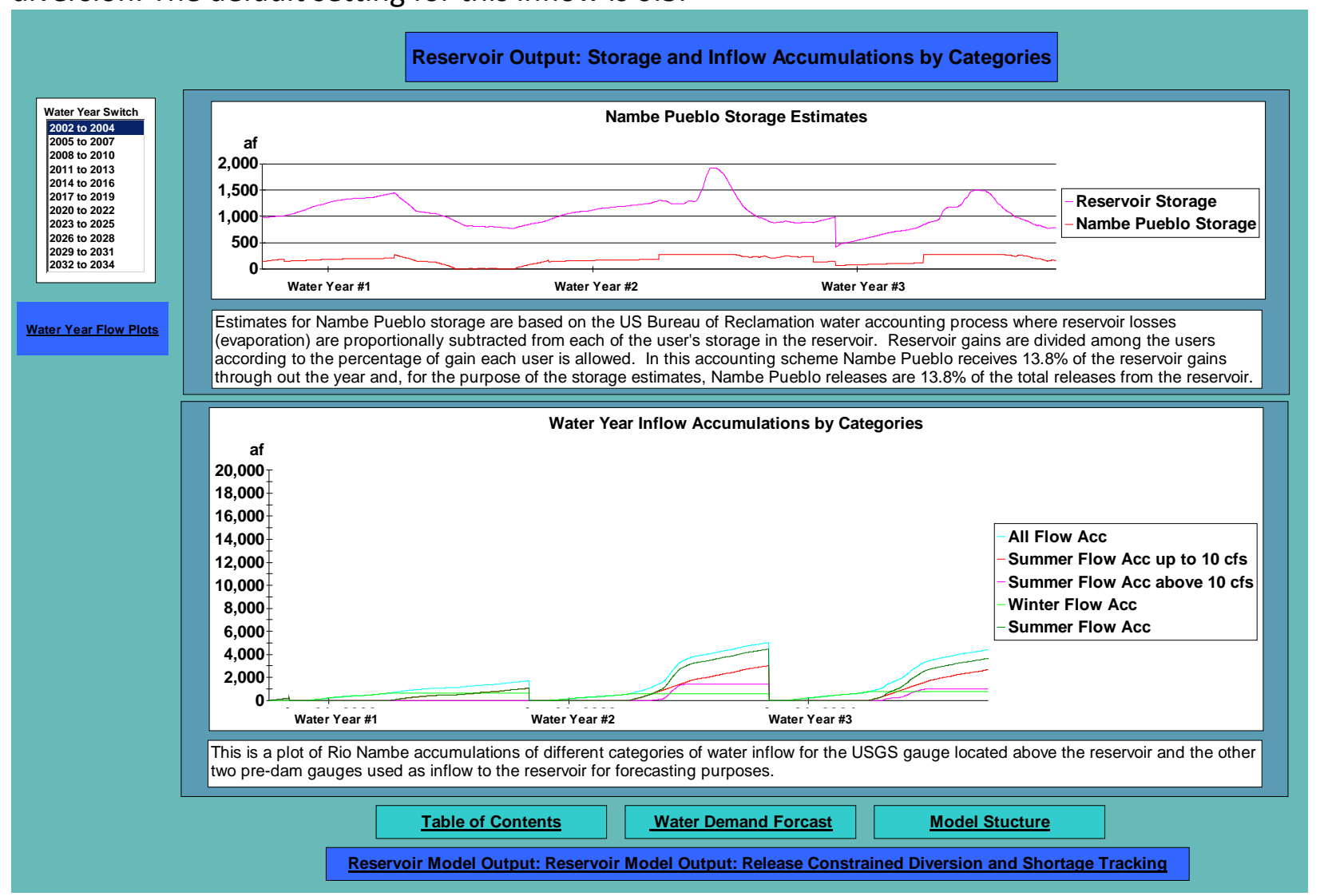

Figure 0-1: Screen shot of the Storage and Inflow Accumulations by Categories page. The Nambe Pueblo portion of the total reservoir storage in Nambe Reservoir for the water years 2002 through 2004 are shown in the upper 
plot. The lower plot shows accumulated quantities for several different categories in inflow. Of particular importance are the flow rates above and below $10 \mathrm{cfs}$ as the Nambe, San Ildefonso, and Pojoaque pueblos are allowed to store or use the natural flows up to $10 \mathrm{cfs}$. Notice the impact of the 2002 water year drought on water accumulation in Nambe Reservoir as compared to the $\mathbf{2 0 0 3}$ and 2004 water years.

In Figure 0-2, the 2002 water year ("Water Year Number 1" on the X axis) was a significantly dry year for the southwest and this condition is reflected in the both of the plots in Figure 0-3 for that year. In the upper plot, the red line shows that for the first irrigation event, the Highline ditch diverted the full $6 \mathrm{cfs}$ while the Consolidated ditch did not obtain the full $6 \mathrm{cfs}$ and despite the deficiency, the Highline diversion ended before the Consolidated diversion.

The second irrigation event during 2002 saw decreased Rio Nambe flows and subsequent decrease in Highline and Consolidated diversion rates with much longer irrigation intervals required to satisfy the irrigation demand. During the 2003 and 2004 water year flows in the Rio Nambe were greater resulting in much shorter irrigation intervals than those experienced in 2002. The contrast between the water availability between 2002 and the later water years is also reflected in the number of days of inadequate flows - those flows that are less than that set for each irrigation. In 2002, the total days of shortage for the Consolidated ditch is about 140 and that of the Highline about 120 in contrast to that of 2003 and 2004 when the shortage days were below 50 .

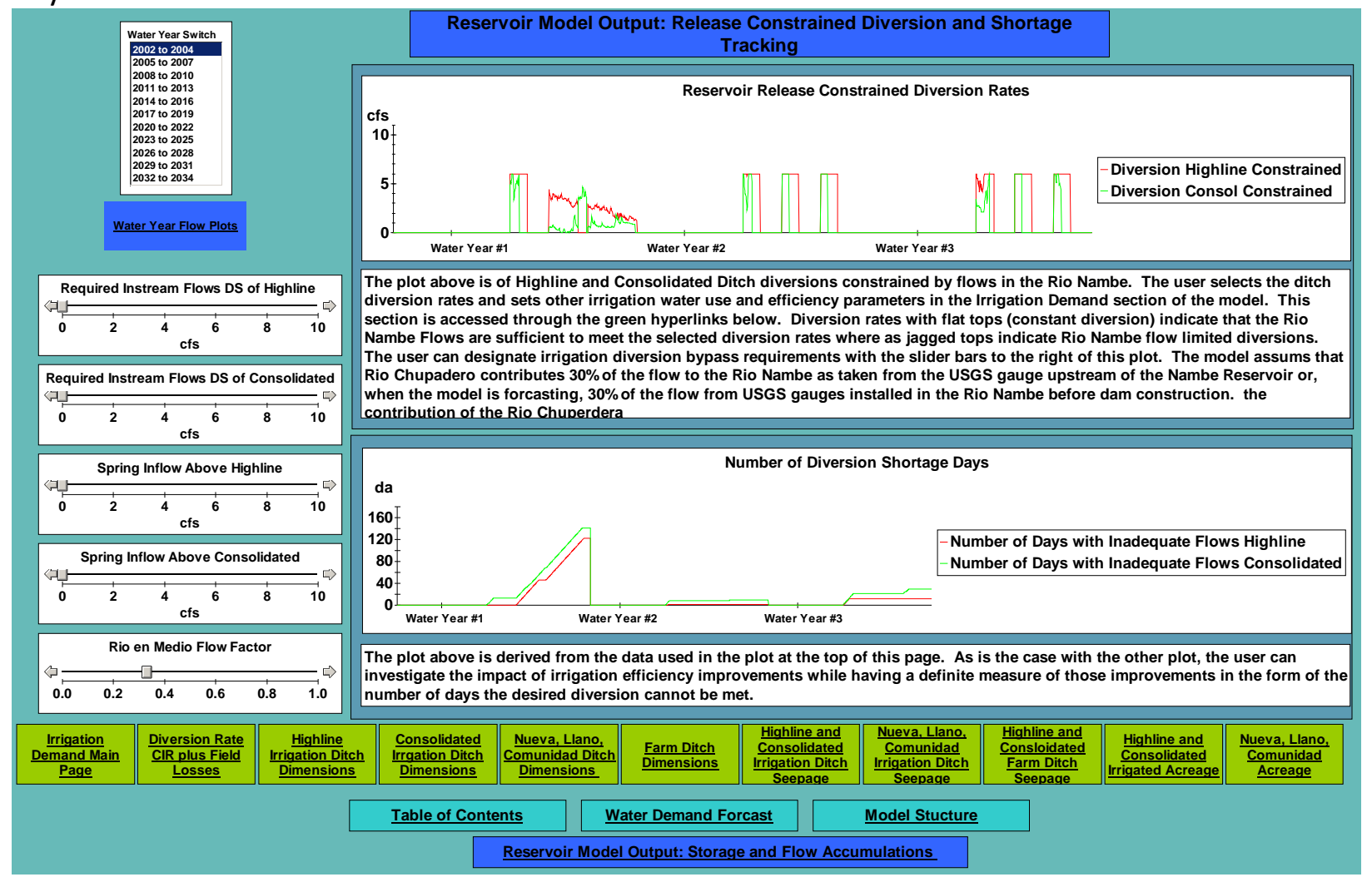

Figure 0-2: Screen shot of the Release, Diversion, and Shortages page. This page contains two plots that are based on the capability of the available stream to meet the irrigation requirements of the Highline and Consolidated ditches. The upper plot shows the impact of reduced stream flows on the irrigation duration while the lower plot records the number of days that the diversion rate is not met for the set irrigation rate. The user can investigate the impact that changes in the irrigation system efficiencies may have on the irrigation duration and number of shortage days by altering many of the parameters in the Irrigation Demand component of the model which can be accessed through the hyperlinks in the green boxes at the base of the page. The user can 
also alter restrictions for meeting down stream deliveries and inputs from springs and a major tributary located on this reach of the river. See the text for more details.

The shorter irrigation interval for the Consolidated ditch versus the Highline Ditch, especially obvious in the 2004 and 2005 water year plots is a reflection of the shorter ditch length of the consolidated ditch, since for this simulation the user set acreages for the Highline and all of the farms that the Consolidated Ditch serves is about the same. This assumes also that the total farm ditch losses from each ditch are about the same.

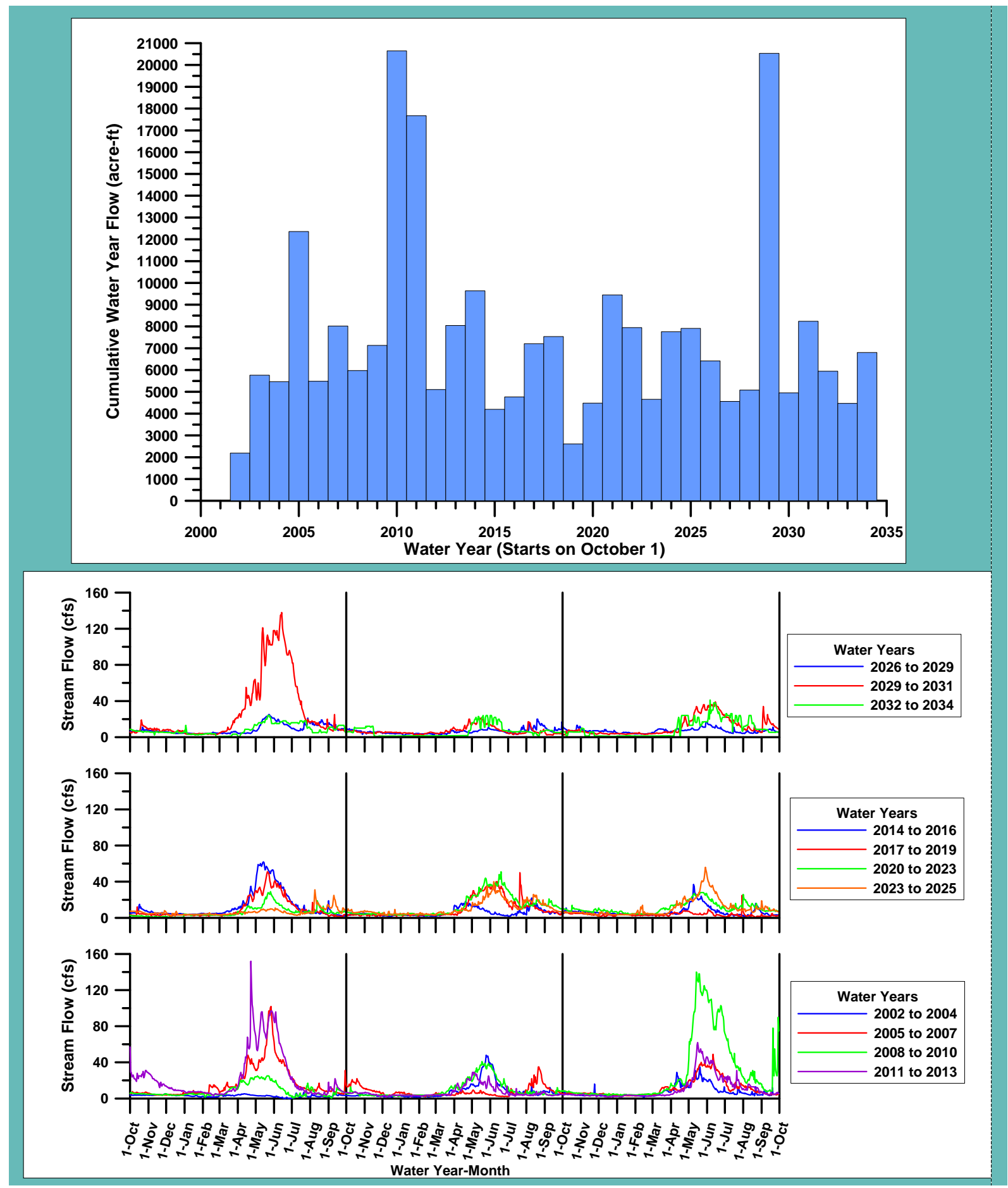


Figure 0-3: Screen shot of the Cumulative Water Year Flow and Stream Flow plots. The cumulative water year plot (upper) reports the volume of water accumulated over the water year for each of the years from 2001 to 2034 while the Stream Flow plots give the stream flow over each the three year intervals that the user can select in the Water Year Switch box.

\section{Running the Model}

This model is built with Powersim Studio ${ }^{\circledR}$ software Release 7 which, unlike later versions (release 8 and presumably later versions), can be converted to a "Studio 7 Player" format that allows it to be played using the "Studio 7 Player" (Player) provided without charge from the software manufacturer. Player is provided on the compact disk that contains the model and this report. To prepare your computer for running the model, the following tasks have to be completed:

1) Copy the Nambe Pueblo Model folder from the $C D$ on to your hard drive

2) Copy the "Player" folder from the CD to your hard drive.

3) Start the Player installation by double clicking on the PS_Studio_Player.exe

4) Follow the instructions to install the software on your computer

5) Once the software is installed on your computer, start the program (there are many ways to start the program in windows).

At the top of the screen is a menu bar as shown in

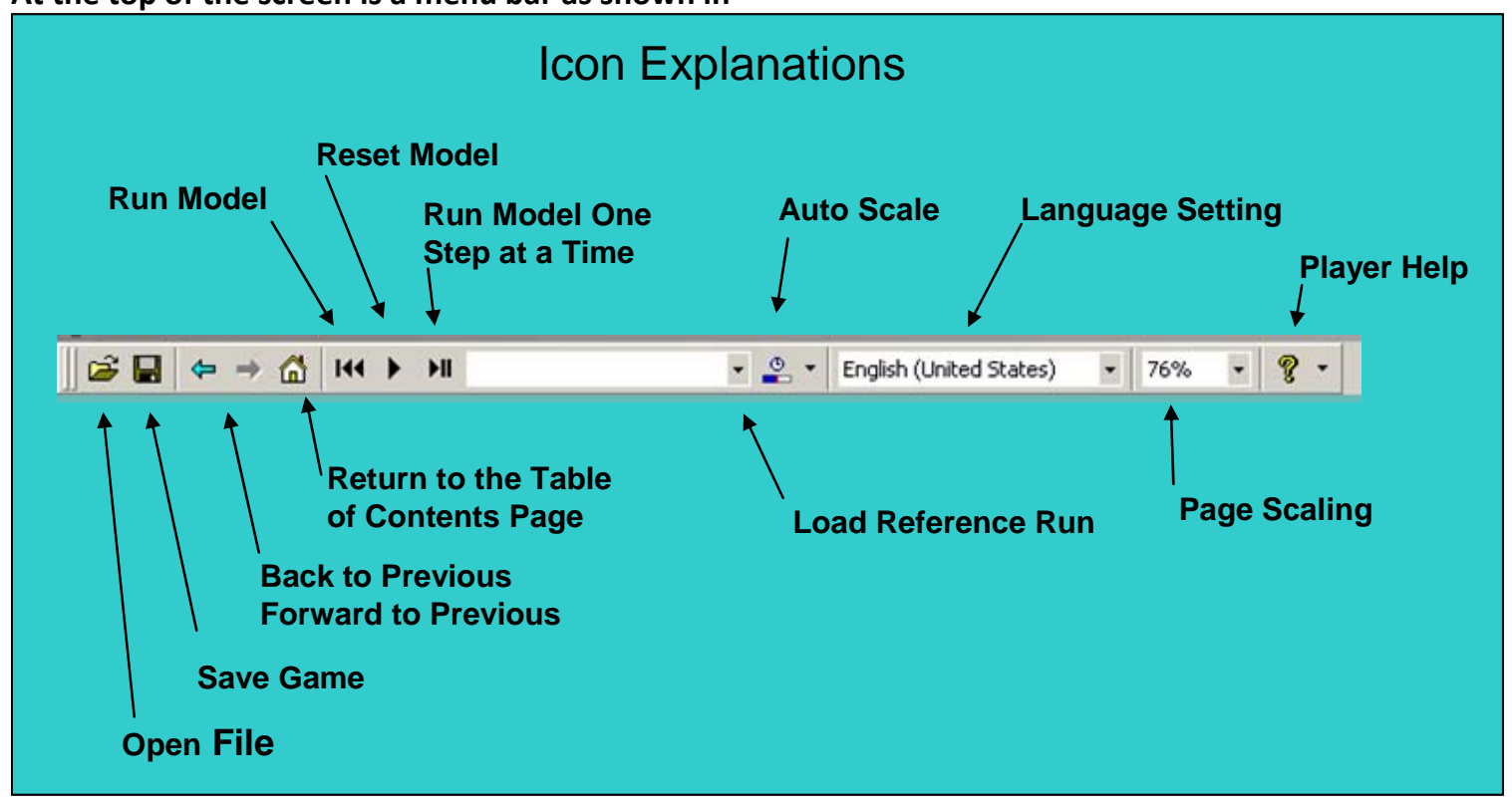

6) Figure 0-1 Click on the folder icon in the menu bar at the top of the page to open the Nambe Pueblo model.

7) The model will open to the "Home Page" which for this model is the Table of Contents page

8) Due to a software bug, you might have to double click on the "Table of Contents" text box to center this page on your computer screen 
For the following operations, refer to

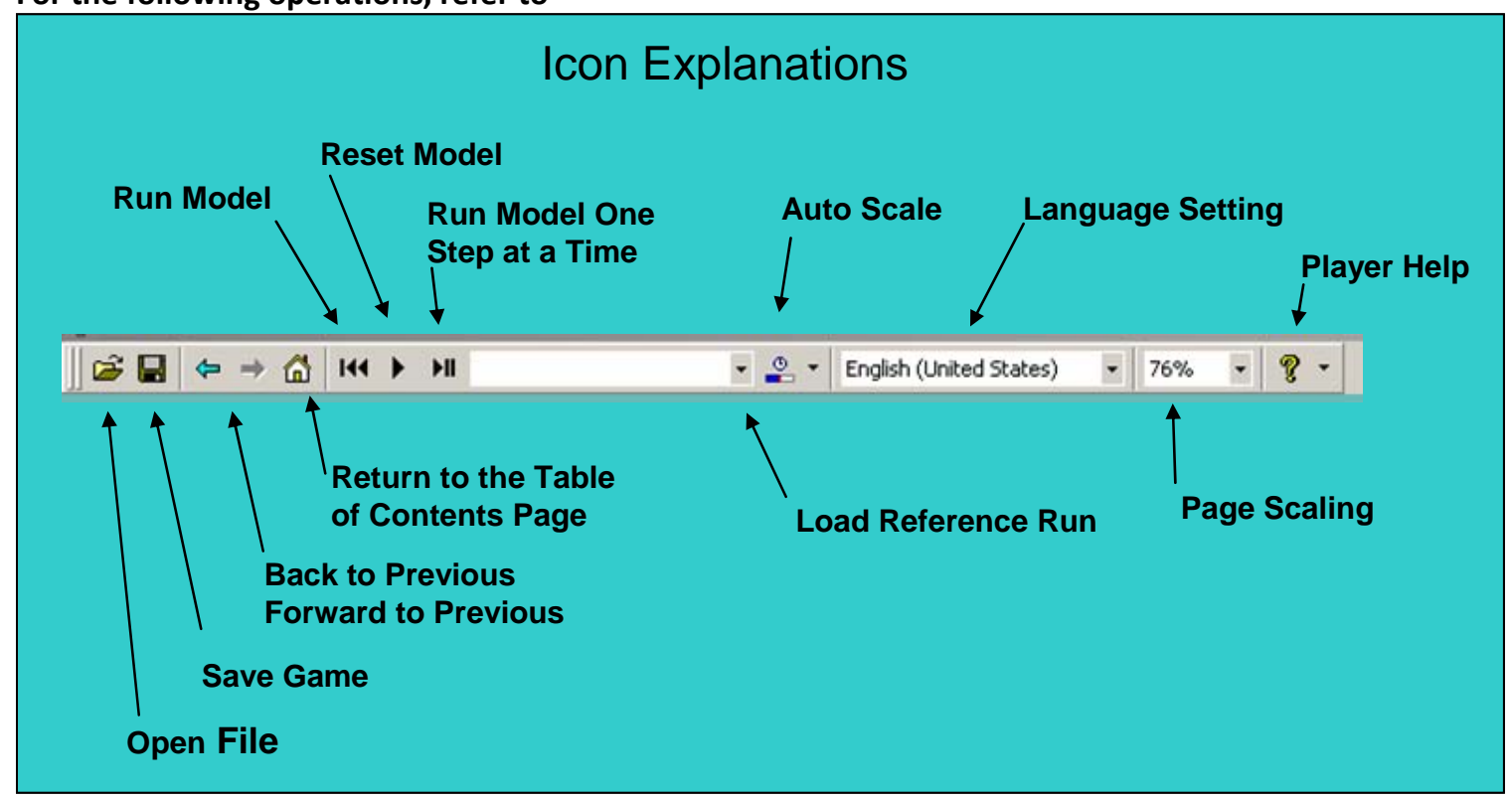

Figure 0-1 for the different icon functions located at the top of the page.

\section{Running the model:}

- The model is "ran" by clicking once on the "Run Model" icon.

- The model is paused by clicking on the "Run Model" icon while the model is running.

- The model is reset to the starting position by clicking on the "Reset Model" icon.

- The model is forwarded one time step by pushing on the "One Time Step" icon. Note that the model must be paused or at it's starting position in order to run the model one time step at a time.

\section{Saving a simulation and showing the results of the saved simulation during the next model} run:

- Run the model and "save" by clicking on the "Save Game" Icon and providing a file name in the standard Windows Save dialog that appears.

- Click on the down arrow in the "Load Reference Run" Icon and click on "Load From File".

- Select the file you want to display for the next run.

- Note that you can also view the "Base Case" scenario by choosing "Base Case" in the Load Reference Run pull down menu. The Base Case Reference Run is the

- Run the model

Note that other icons are available for the user to work with such as "Auto Scale", "Language Setting", and Player Help. The first two have no functionality in this model, and help contains a comprehensive description of the functionality of this toolbar. 


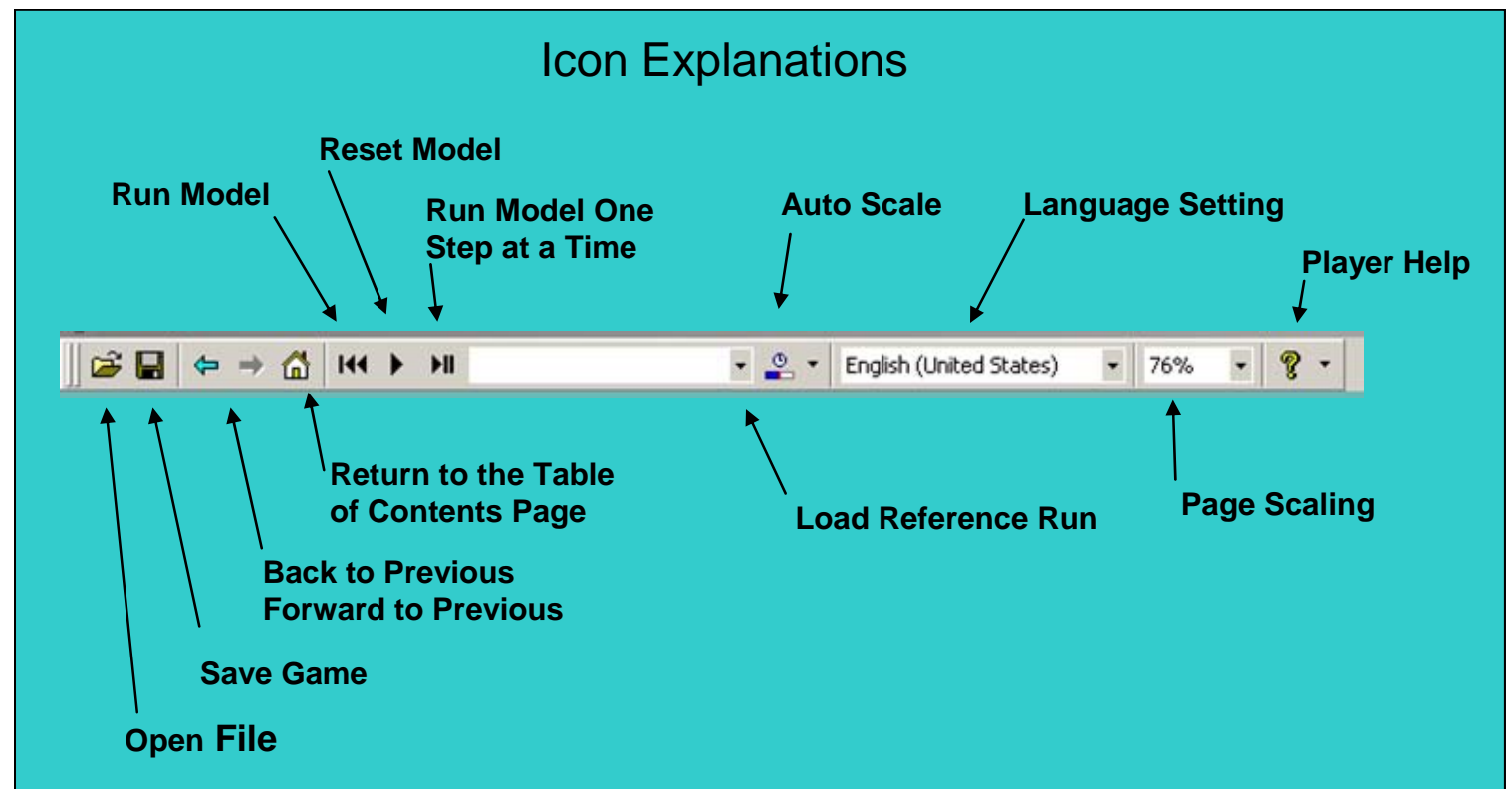

Figure 0-1: Illustration of the Player Toolbar with icon descriptions. 


\section{Summary}

The Nambe Pueblo Water Budget and Water Forecasting Model has been documented in this report in sufficient detail to allow the user to understand the fundamentals of the model calculations, the options for model inputs, and the simulated results. The user is encouraged to "play" with the model to become familiar with all of the components and to run comparison runs using the "Save Game" and "Load reference Run" features of the model. 


\section{References}

Hargreaves, G.H. 1975. "Moisture availability and crop production," Trans. Am. Soc. Agric. Eng. 18(5):980-984.

Jack Veenhuis, USGS Hydrologist, Personal Communication, November, 2007.

NOAA, National Environmental Satellite, Data, and Information Service

(http://lwf.ncdc.noaa.gov/oa/climate/stationlocator.html) COOP ID 293031, Station Name:

Espanola, 28 march 1938 to Present.

USDA, 2001. Farm Irrigation Rating System for New Mexico, USDA Technical Note, Agronomy

62, July.

USGS Earth Resources Observation and Science Center, Digital Orthophoto Quadrangles.

(http://eros.usgs.gov/products/aerial/doq.php).

US Bureau of Reclamation, 2001 to 2006. Water Accounting Reports, Upper Colorado Regions, Albuquerque Area Office, Albuquerque, NM.

Jack Veenhuis, USGS Hydrologist, Personal Communication, November, 2007. 


\section{Appendix A}

The Hargreaves' Equation uses solar radiation and maximum and minimum daily temperatures for this calculation:

$$
E=0.0023 S_{o}(T+17.8) \sqrt{\delta_{T}}
$$

Where:

$T=$ temperature $\left[{ }^{\circ} \mathrm{C}\right]$

$\delta_{T}=$ difference between daily maximum and daily minimum temperatures

$S_{o}=$ solar radiation $=15.392 d_{r}\left(\omega_{s} \sin \phi \sin \delta+\cos \phi \cos \delta \sin \omega_{s}\right)$

$\phi=$ latitude of the site ( + in the northern hemisphere, - in the southern)

$\omega_{s}=$ the sunset hour angle [radians] $=\arccos (-\tan \phi \tan \delta)$

$\delta=$ solar declination on day J (Julian day) of the year [radians]

$d r=$ relative distance of the earth from the sun on day $\mathrm{J}=1+0.033 \cos \left(\frac{2 \pi}{365} j\right)$. 


\section{Appendix B}

Seepage calculations are based on user specified Seepage $\left[\mathrm{ft}^{3} / \mathrm{da}\right]$ the following Seepage equation:

Equation 0-1: $\quad S=(2 d+w) l S_{r}$

Where:

$d=$ depth of water in the ditch [ft]

$w=$ ditch width at water line $[\mathrm{ft}]$

$l=$ length of ditch section $[\mathrm{ft}$ ]

$S_{r}=$ Seepage rate $\left[\mathrm{ft}^{3} / \mathrm{ft}^{2} / \mathrm{da}\right]$. 